\title{
Palaeoenvironmental history of Bap-Malar and Kanod playas of western Rajasthan, Thar desert
}

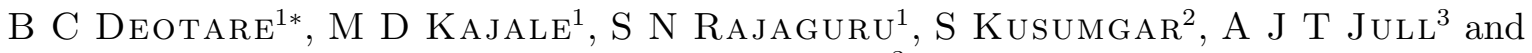 \\ J D DONAHUE \\ ${ }^{1}$ Deccan College, Postgraduate and Research Institute, Pune 411 006, India. \\ *e-mail:prag21@vsnl.net \\ ${ }^{2}$ Physical Research Laboratory, Navrangpura, Ahmedabad 380 009, India. \\ ${ }^{3}$ Radiocarbon Laboratory, Department of Physics, University of Arizona, Tuscon, USA.
}

\begin{abstract}
Two playas in the arid core of the western margin of the Thar desert viz., Bap-Malar and Kanod, have been investigated using palynology, geomorphology, archaeology, AMS-radiocarbon dating, stable isotopes, evaporite mineralogy and geoarchaeology. The principal objective was to obtain a reliable lithostratigraphy of the playa sediments. These are about $7 \mathrm{~m}$ thick in the Bap-Malar and $>2.5$ to $3 \mathrm{~m}$ thick in the Kanod. AMS ${ }^{14} \mathrm{C}$ dates of $>15 \mathrm{ka} \mathrm{BP}$ on pollen from sediment layers indicates that the Bap-Malar playa possibly existed even during the LGM. These playas were full of water during the early Holocene ( $8 \mathrm{ka} \mathrm{BP}-5.5 \mathrm{ka} \mathrm{BP})$ and were ephemeral during the PleistoceneHolocene transition and early to mid to late Holocene. The playas dried almost 1000 years earlier than those occurring on the eastern margin. Pollen of graminaceae, chenopodiaceae/amaranthaceae, cyperaceae etc. and evaporite minerals like gypsum, halite in the profiles indicate that the playas were surrounded by vegetation dominated by grass and that, they remained brackish to saline even during the mid Holocene, lake full stage. Stable dune surfaces, pediments with regoliths, and gravelly channels of ephemeral streams provided a favorable geomorphic niche for nomadic human activity since $\sim 7 \mathrm{ka}$ BP. Though local ecological factors have played an important role in the evolution of the playas, the winter rains, connected with northwesterly depressions, most likely played a vital role in maintaining these playas.
\end{abstract}

\section{Introduction}

Earlier studies on the vegetational history (Singh et al 1974, 1990), mineralogy and geochemistry (Wasson et al 1983; Roy et al 2001), lithostratigraphy and pollen analytical studies (Sharma and Chauhan 1991; Deotare and Kajale 1996; Kajale and Deotare 1997; Deotare and Kajale 2002) on saline lakes in Rajasthan have provided a firm foundation for further scientific studies. Recent advances in luminescence dating of sand dunes and application of AMS ${ }^{14} \mathrm{C}$ dating to organically poor playa sediments, stable isotope studies of carbon and oxygen of pedogenically formed carbonates within aeolian, fluvial and fluvio-lacustral sediments have enhanced understanding of the palaeoenvironment of the Thar desert (Enzel et al 1999; Thomas et al 1999; Kajale et al 1999; Juyal et al 2000; Kajale et al 2000; Kajale et al 2002).

The Thar desert had a mixture of C3 and C4 plants during the early Quaternary when the climate was relatively wet, though semi-arid. The landscape was supported by the fluvial systems with groundwater close to or above the land surface. Extensive development of calcrete, lithic as well as nodular, over most of the Thar, is a major geomorphic expression of the early Quaternary (Dhir et al 1999; this volume).

By the late middle Pleistocene (> $200 \mathrm{ka})$, the climate became distinctly semi-arid to arid as

Keywords. Palaeoenvironment; Thar desert; playas; pollen analysis; geoarchaeology. 
reflected by the development of calcretes, anastomising drainage with playas, and dunes and sand sheets over the entire Thar. Palaeolithic Man appeared in the desertic landscape and camped on the banks of seasonally flowing streams, shorelines of playas, stable dune surfaces and on rocky pediments (Misra and Rajaguru 1989). The C4 plants dominated the biomass during this period.

During the late Pleistocene ( 100 ka onwards) the aridity increased and the fluvial system turned ephemeral. Ground water lowering was considerable, aeolian sedimentation was episodic and more intense during the transitional climatic phases (from arid to semi-arid) than during the peak of the arid climate. Dunes that are inactive today contain evidence of multiple phases of accumulation during which winds were stronger and more consistent, rather than a climate that was simple dry (Thomas et al 1999).

Complimentary to the dune record, Singh et al (1974, 1990) studied late Quaternary playas in the Thar desert. These pioneering multi-disciplinary studies showed that the Didwana playa in the eastern margin of the Thar existed since the LGM and had a lake-full, fresh water phase during the early to mid Holocene $(7 \mathrm{ka}-4 \mathrm{ka})$. They also suggested a correlation between climatic amelioration, and growth and decay of Harappan culture in northwestern India. The studies by Singh et al were later perused by Deshmukh and Rai (1991) and by Deotare and Kajale (1996). These studies suggest that the playa like Didwana existed even during late Pleistocene and mineralogical and palynological data on playas like Thob, Pachpadra, Kuchaman, Pokaran did not suggest a major departure in climatic conditions during the early-mid Holocene from what was suggested by Singh et al. The present paper focuses on two playas, Bap-Malar (District Jodhpur) and Kanod (District Jaisalmer) in the arid core of the western margin of the Thar (figure 1) and presents results from a multidisciplinary study. These include, geomorphological, lithostratigraphical, palynological and archeological studies complimented by AMS ${ }^{14} \mathrm{C}$ dates along with stable isotopic data on pollen-spores concentrates. A chronologically constrained palaeoenvironmental record is finally presented.

Present investigations show that the winter monsoon of northwest India has played an effective role in maintaining playas in the arid core of the Thar desert since the Last Glacial Maximum. The Mesolithic hunter-gatherers camped on the stable surface of dunes during the early Holocene $(\sim 7 \mathrm{ka})$, and the pastoral semi-nomadic population continued to subsist on the banks of ephemeral streams during the late Holocene $(\sim 1.5 \mathrm{ka} \mathrm{BP})$ as inferred from both the scores of archaeological sites around Bap-Malar (Deotare et al 1998) and in early historic site buried in channel gravel at Bari-Bavri (Deotare et al 1999).

\section{Methods}

Two pits (W9 \& W10) at Bap-Malar (figure 2), to a depth of about $4 \mathrm{~m}$, were excavated during 1996-1998 and a cm scale log of the sequence was prepared. These trenches, along with earlier lithostratigraphy based on eight trenches (W1 to W8) dug during 1988-1993 and studied by Kajale and Deotare (1995, 1997), facilitated the understanding of both the basal pre-depositional configuration and sedimentary succession of the playa.

At Kanod, additional three pits (K3, K4 and K5) were dug to obtain a reliable lithostratigraphy together with the earlier two pits (K1 and K2) from northwestern edge of the playa (figure 3 ). The pits $\mathrm{K} 3$ and $\mathrm{K} 5$ are in the central portion of the playa and separated by a distance of $2-3 \mathrm{~km}$. The $\mathrm{K} 4$ trench is near the playa shore.

\subsection{Particle-size analysis}

A few samples were analysed by using the pipette method by Day (1965) and Piper (1966). The silt and clay fractions were measured whereas the coarse sand was calculated by difference. The fine sand fraction was obtained by subtracting the total of coarse sand, silt and clay from 100.

\subsection{Routine chemical analysis}

A few representative samples were analysed for the following chemical parameters.

- $\mathrm{pH}$ was determined using a portable $\mathrm{pH}$ meter by using glass electrode in 1:2.5 soil water suspensions as described by Jackson (1962).

- Calcium carbonate was determined by the rapid titration method as given by Piper (1966).

- Organic carbon was carried out by using the sulphuric acid-dichromate oxidation method followed by colorimetric measurement as described by Datta (1962).

\subsection{Pollen extraction}

The technique described by Faegri and Iversen (1964) and Traverse (1988) was used for pollen extraction. In order to increase the pollen concentration, the hydrofluoric acid treatment followed by heavy density seperation using zinc chloride was also used to remove silica and to obtain clean preparations. 


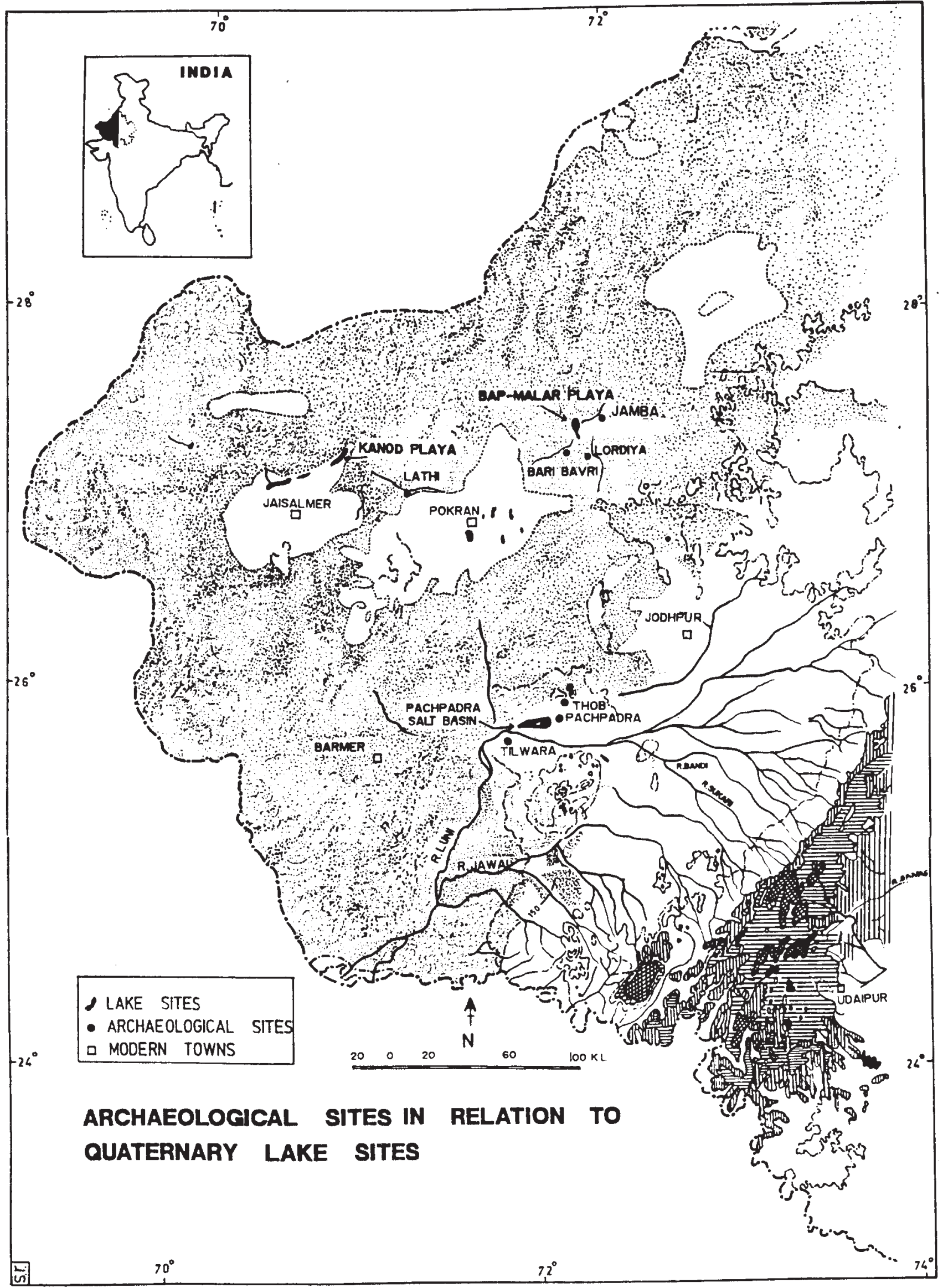

Figure 1. Archaeological sites in relation to Quaternary lake sites. 


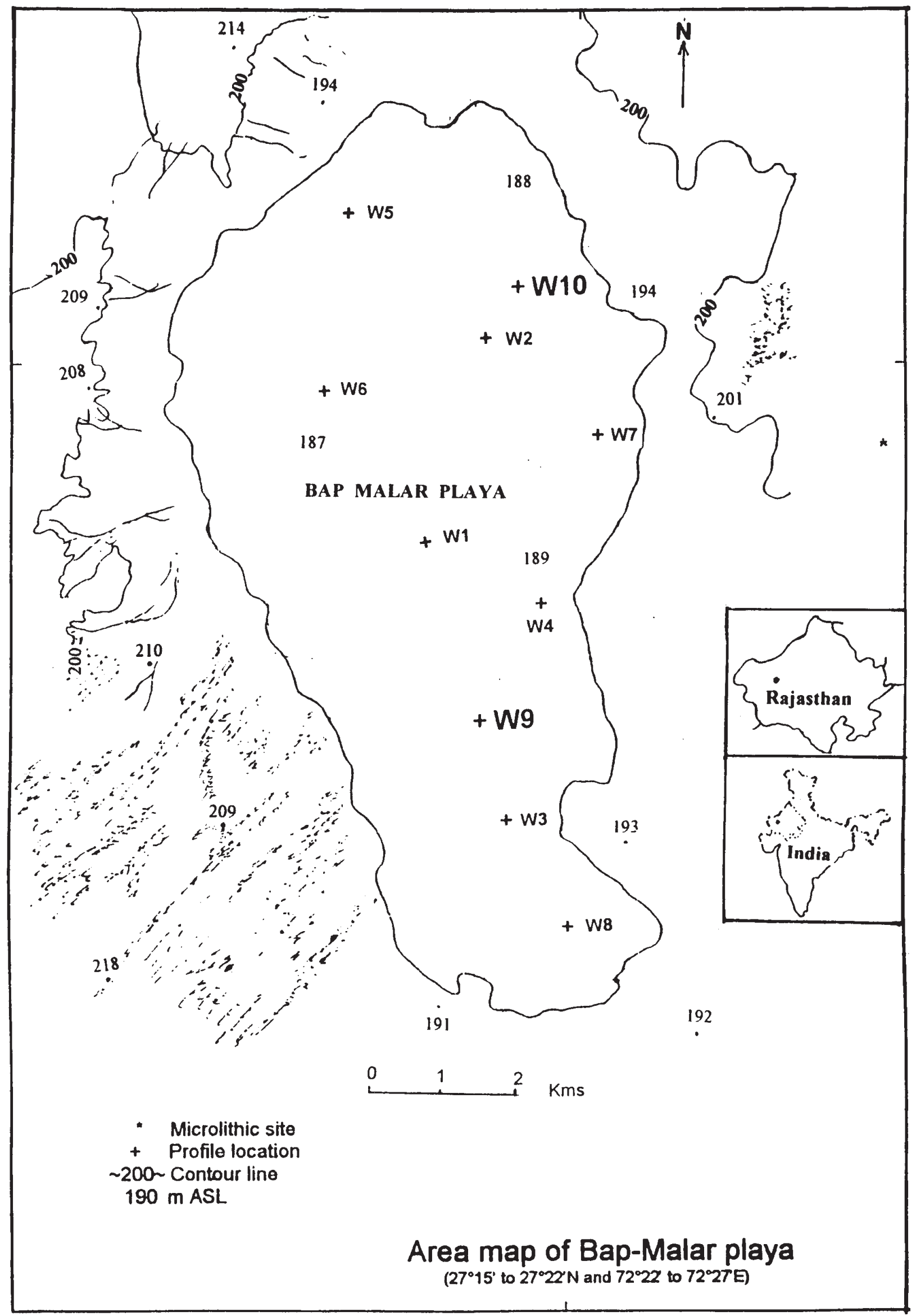

Figure 2. Area map of Bap-Malar playa showing the location of trenches. 


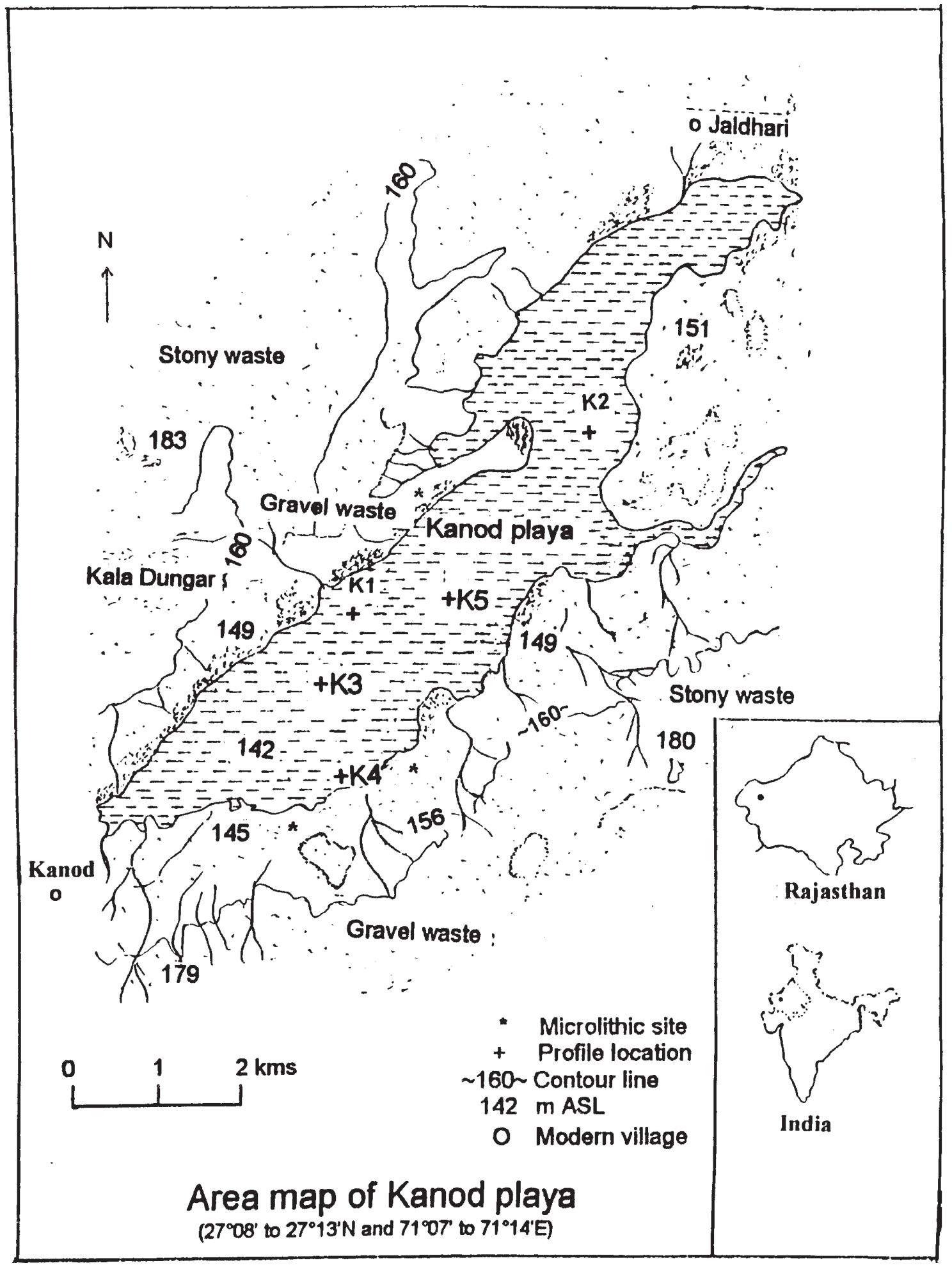

Figure 3. Area map of Kanod playa showing the location of trenches.

\subsection{XRD analysis}

Evaporite and clay mineralogical studies were carried out on the RIGAKU XRD equipment using the $<100 \mu \mathrm{m}$ fraction and XRD patterns were recorded at $45 \mathrm{KV}, 30 \mathrm{~mA}$ at scan speed of $2^{\prime} / \mathrm{sec}$. Preliminary XRD analysis of the playa sediments showed more or less no clay minerals such as montmorillonite, illite, kaolinite etc. As a result, no pretreatment and orientation was given to the playa samples. 


\subsection{Dating}

In the absence of sufficient organic material, standard radiocarbon age determinations were difficult to achieve. As a result, accelerator mass spectrometric (AMS) radiocarbon dating was employed at the Arizona state AMS radiocarbon laboratory, USA.

For this dating, pollen concentrates were used. A $20 \mathrm{~g}$ sample was treated with $18 \% \mathrm{HCl}$ for $12 \mathrm{hr}$ to remove the carbonate fraction and to disaggregate the silt fraction. The residual was treated with $40 \% \mathrm{HF}$ for $12 \mathrm{hr}$ to digest the silicate fraction and then sequentially with $18.5 \% \mathrm{HCl}, 10 \%$ $\mathrm{NaOH}$ to remove the humic acid fraction. The final residue was treated again with $18.5 \% \mathrm{HCl}$ and dried. Approx. 80-200 mg of pollen rich residue was combusted with $\mathrm{CuO}$ to form $\mathrm{CO}_{2}$. The $\mathrm{CO}_{2}$ was then reduced to graphite for final AMS analysis (Slota et al 1987; Donahue et al 1984).

\section{Field and laboratory studies}

In order to have a better understanding of litho units exposed in playas, a reconnaissance survey of geomorphological features (including regolith) surrounding the playas was undertaken. Details of these field observations are briefly described below.

The Bap-Malar and Kanod playas occur in depressions formed on pediment surfaces, varying in elevation from about 250 to $150 \mathrm{~m}$ above mean sea level. These pediments have developed over Proterozoic and Mesozoic sediments comprising limestone, sandstone, shale and conglomerate (boulder beds) (Sinha-Roy et al 1998). The depressions are possibly structural depressions (Roy 1999), disorganised palaeochannels (Anand Prakash 1980) or the result of strong wind erosion (Kar 1995). In both the playas, channel gravel beds, or fossil dune sediments or other non-playa sediments were found over the weathered bedrock. The age and origin of the depressions remains uncertain. Other geomorphic features observed in the area around the playas were as follows.

\section{(a) Ferricretes and calcretes}

Ferricretes and lithic calcretes occur as regolith capping pediments developed over Mesozoic sediments in the surrounding area of both the playas. These duricrusts have been tentatively dated to Neogene and early Pleistocene respectively (Dhir et al 1992; Achuthan 1999). Relief inversion of isolated outcrops of duricrusts is common. Geomorphic and mineralogical characters of these duricrusts suggest sub-humid to semi-arid climate during the Neogene and early Pleistocene and considerable lowering of ground water in later Quaternary due to increased aridity (Mehr Homji 1978).

\section{(b) Sand dunes and sandsheets}

They are important components of the JodhpurJaisalmer region. Weakly pedogenised stable dunes with rich scatter of microlithic artefacts are part of the parabolic dune system of this region (Kar 1995; Wadhavan and Sharma 1997) and are of late Pleistocene age (Dhir et al 1992).

Gypsum pans are well developed around Mohangarh in depressions between dune sands of late Pleistocene age. Microliths are found on biocrustated sand-surfaces around Mohangarh. Field observations on aeolian sands in the arid parts of the rocky upland are in conformity with detailed geomorphological and luminescence dating of aeolian sands of the Thar desert by Kar et al (1998), Thomas et al (1999) and Juyal et al (2000).

\subsection{Bap-Malar playa}

The Bap-Malar Rann $\left(27^{\circ} 15^{\prime}\right.$ to $27^{\circ} 22^{\prime} \mathrm{N}$ and $72^{\circ} 22^{\prime}$ to $72^{\circ} 27^{\prime} \mathrm{E}$ ) is a closed dry basin with an area of about $78 \mathrm{~km}^{2}$ located $\sim 150 \mathrm{~km}$ northwest of district town of Jodhpur in western Rajasthan (figure 1). A few insignificant ephemeral streams, particularly on the southwestern side feed the basin. The sources of water to the lake basin are rainfall and ground water. The water table is currently 8 to 10 meters below the dry surface of the playa (also called as rann in the local dialect). The salinity of the water consists of chlorides of sodium, calcium and magnesium, and sulphates and bicarbonates. Except during peak monsoon (July-August), when the rann gets flooded to a depth of several meters, it is dry with a salt encrusted surface for about 8 to 10 months. The flooding of the surface is not regular with high intra annual variability (standard deviation 80\%) in (mean) annual rainfall of about $200 \mathrm{~mm}$. The mean annual evaporation is around 2000 mm (India Meteorological Department, 1988) suggesting a net water deficit during most of the year. The present vegetation is thorn and scrub type and is dominated by Aerva persica, Aerva pseudotomentosa, Cassia auriculata, Acacia sps. on the stabilised dune surfaces. The possible source of the sediments to the rann is aeolian sand from the surrounding dunes, and silt and sand from the ephemeral streams.

Eight pits (W1 to W8) were dug during earlier investigations (Kajale and Deotare 1995) to explore the lithostratigraphy and pollen analytical potential. Subsequently two additional pits (W9 
Table 1. AMS radiocarbon dates and $\delta^{13} C$ on the deposits from Bap-Malar playa.

\begin{tabular}{|c|c|c|c|c|c|c|c|}
\hline $\begin{array}{l}\text { Sr. } \\
\text { no. }\end{array}$ & Trench & $\begin{array}{c}\text { Sample } \\
\text { no. }\end{array}$ & $\begin{array}{l}\text { Depth in } \\
\mathrm{cm}\end{array}$ & Lab code & $\begin{array}{c}\delta^{13} \mathrm{C} \\
\text { permil }\end{array}$ & $\begin{array}{c}{ }^{14} \mathrm{C} \text { age } \\
(\mathrm{aBP})\end{array}$ & $\begin{array}{c}\text { Calibrated } \\
\text { age }(1 \sigma) \\
(\mathrm{a} \text { BP })\end{array}$ \\
\hline 1 & W10 & TR 63 & $380-384$ & V14192 & -17.814 & $15,370 \pm 120$ & $\begin{array}{l}18,430 \text { to } \\
18,140\end{array}$ \\
\hline 2 & W10 & TR 61 & $318-322$ & V14191b & -16.547 & $10,630 \pm 80$ & $\begin{array}{l}12,660 \text { to } \\
12,450\end{array}$ \\
\hline 3 & W10 & MLR20 & $235-240$ & V14180 & -18.399 & $11,240 \pm 110$ & $\begin{array}{l}13,275 \text { to } \\
13,030\end{array}$ \\
\hline 4 & W10 & MLR21 & $140-145$ & V14181 & -15.654 & $7900 \pm 70$ & $\begin{array}{l}8940 \text { to } \\
8550\end{array}$ \\
\hline 5 & W10 & MLR23 & $130-140$ & V14183 & -14.598 & $6955 \pm 60$ & $\begin{array}{l}7870 \text { to } \\
7660\end{array}$ \\
\hline 6 & W10 & MLR22 & $90-95$ & V14182 & -16.194 & $7320 \pm 75$ & $\begin{array}{l}8140 \text { to } \\
7990\end{array}$ \\
\hline 7 & W10 & MLR22 & 90-95 & V14182A & -16.200 & $7460 \pm 60$ & $\begin{array}{l}8320 \text { to } \\
8140\end{array}$ \\
\hline
\end{tabular}

and W10) were dug during 1996 to obtain samples for AMS ${ }^{14} \mathrm{C}$ dating, XRD, pollen analysis (figure 2). The W10 pit was selected for detailed laboratory studies, because it was the most representative section and was in the deepest part of the playa.

Texturally, almost all the samples of W10 are dominated by sand and silt fraction. There is no clay-dominated sediment. Even in a sample of white sediment containing $16.1 \%$ clay, chemically precipitated powdery gypsum was a dominant component. The sediments from W9 \& W10 are alkaline with $\mathrm{pH}$ ranging from 7.8 to 10 . The organic carbon is low in both the profiles. In W10, three samples from 50 to $120 \mathrm{~cm}$ depth had organic carbon $\sim 0.6 \%$. As these sediments are deficient in organic carbon and low in clay content, AMS dates were tried on pollen concentrates (table 1 ).

\section{1a Lithostratigraphy}

The composite stratigraphic succession is based on the logs of ten trenches (figure 4), the main features of which are as follows:

Lithounit I $(320-650 \mathrm{~cm})$ comprises thick laminae of quartz fine sand ranging in colour from pinkish white $(7.5 \mathrm{YR} 8 / 2)$ to pinkish grey $(7.5 \mathrm{YR}$ $7 / 2$ ). The sand laminae include post-depositional thin carbonate coatings, on sand grains and some beds are disturbed. This sand dominated unit is interbedded with well-laminated greyish silt with gypsum crystals varying in size from 0.2 to $1.5 \mathrm{~mm}$. These crystals cut across the bedding plain of siltsand laminae, and are found below the surface.
This unit is almost devoid of surface evaporites like powdery gypsum as observed in unit III, and also exhibits cross lamination and lag concentrates of granules and pebbles of quartz below $4 \mathrm{~m}$. Laminae between 5.20 and $5.30 \mathrm{~m}$ are devoid of gypsum. An AMS ${ }^{14} \mathrm{C}$ date at a depth of $380 \mathrm{~cm}$ indicates deposition of the upper part of this unit began around $15 \mathrm{ka}$, and the lower part of the unit is certainly older than $15 \mathrm{ka}$ and could possibly be extended to the Last Glacial Maximum (table 1).

Lithounit II $(180-320 \mathrm{~cm})$ consists predominantly of finely laminated silt and fine sand, with interlayering of powdery gypsum laminae with gentle ripple bedding, particularly between 250 and $320 \mathrm{~cm}$, indicating very shallow water depth. The clastic sediments are light grey (10 YR 7/1) and contain gypsum as a principal evaporate mineral, with the exception of a laminae between 220 and $260 \mathrm{~cm}$, which is devoid of gypsum. The upper part $(180-220 \mathrm{~cm})$ is rich in post-depositional gypsum with crystals as large as $12 \mathrm{~cm}$. These megagypsum crystals cut across the bedding of siltsand laminae. The laminae between 220 and $260 \mathrm{~cm}$ have yielded a good number of pollen represented by morphotypes of cyperaceae, chenopodiaceae/ amaranthaceae, gramineae, typhaceae, compositae, salvadoraceae, ephedraceae, etc. which represent mixed assemblage of species found in moist margins of modern playas and surrounding dry dunes. The arboreal pollen grains are rather rare, thereby suggesting locally prevailing steppe like conditions. Laminae down to $320 \mathrm{~cm}$ show alternations between greyish silt, fine sand and gypsum formed on the playa surface. Gentle wavy bedding 


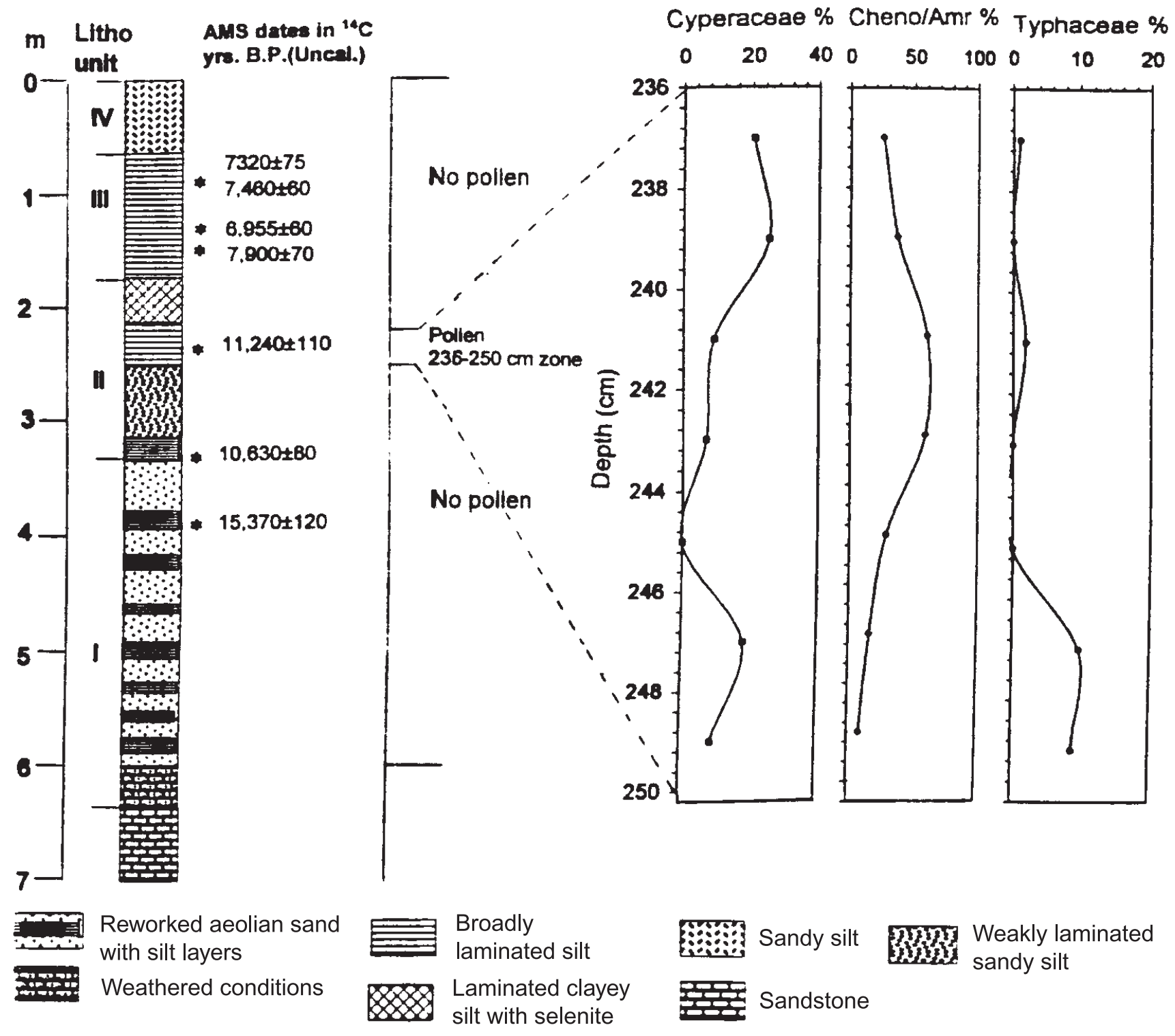

Figure 4. (Continued on facing page)

Table 2. Lithostratigraphy and palaeoenvironment of Bap-Malar playa.

\begin{tabular}{|c|c|c|c|}
\hline Unit & $\begin{array}{l}\text { Depth in } \\
\mathrm{cm}\end{array}$ & Character & $\begin{array}{l}\text { Approx. age and } \\
\text { environment }\end{array}$ \\
\hline & $>650$ & Reddish sandstone & Mesozoic \\
\hline I & $650-320$ & $\begin{array}{l}\text { Thickly laminated reworked aeolian } \\
\text { sand with intercalations of silt and } \\
\text { gypsum laminae. }\end{array}$ & $\begin{array}{l}\text { Terminal Pleistocene } \\
(>15 \mathrm{ka}) . \text { Shallow ephe- } \\
\text { meral lake }\end{array}$ \\
\hline II & $320-180$ & $\begin{array}{l}\text { Finely laminated grayish silt-fine } \\
\text { sand with intercalations of powdery } \\
\text { gypsum, rich in selenite crystals in } \\
\text { upper part, pollen present. }\end{array}$ & $\begin{array}{l}\text { Early Holocene (basal) } \\
(\sim 11-10 \mathrm{ka}) . \quad \text { Shallow } \\
\text { and seasonal, at times } \\
\text { dry }\end{array}$ \\
\hline III & $180-60$ & $\begin{array}{l}\text { Finely laminated grayish silt-fine } \\
\text { sand without prominent gypsum. }\end{array}$ & $\begin{array}{l}\text { Early Holocene }(8-7 \mathrm{ka}) \text {. } \\
\text { Lake full phase, yet shal- } \\
\text { low and saline }\end{array}$ \\
\hline IV & $60-0$ & $\begin{array}{l}\text { Reddish brown pedogenised thickly } \\
\text { laminated silt-fine sand. }\end{array}$ & $\begin{array}{l}\text { Mid to Late Holocene } \\
(<6 \mathrm{ka}) \text {. Lake dry phase }\end{array}$ \\
\hline
\end{tabular}




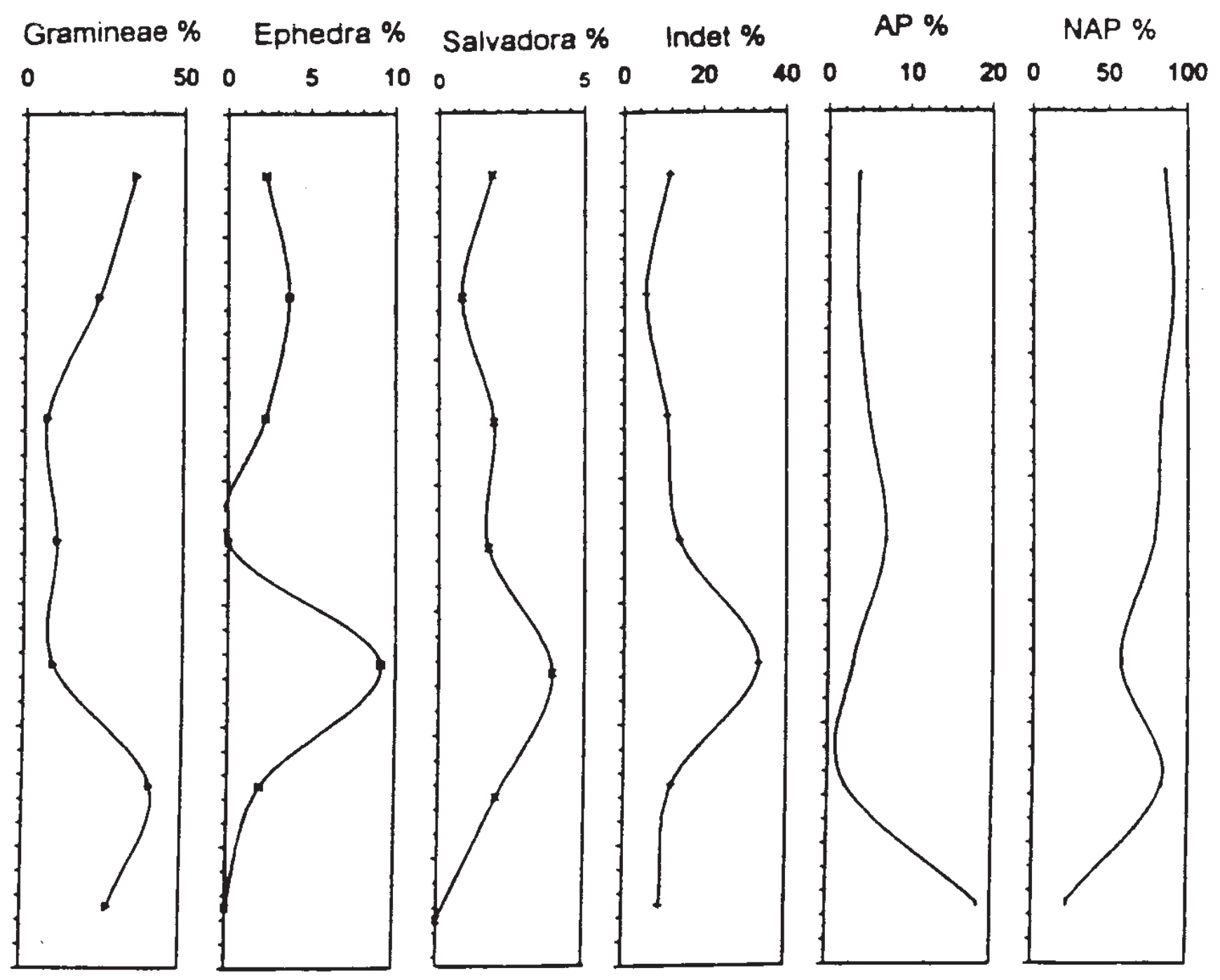

Figure 4. Pollen distribution in W10 trench of Bap-Malar playa.

is common in these laminae. This unit (particularly $320-330 \mathrm{~cm}$ ) seems to have been deposited between $10.5 \mathrm{ka}$ and $11 \mathrm{ka}$.

Lithounit III $(60-180 \mathrm{~cm})$ is finely laminated, light grey (10 YR 7/1) silt and fine quartz sand with a few lenses of gypsum sand. Clastic laminae vary in thickness from $0.5 \mathrm{~cm}$ to $2-3 \mathrm{~cm}$. This unit is observed in all the ten trenches and serves as a marker bed. Chlorite, muscovite, quartz, plagioclase, calcite, and halites are present. Three AMS ${ }^{14} \mathrm{C}$ dates on organic matter indicate that the unit was deposited during $8-7 \mathrm{ka}$ BP. This unit has a sharp contact with upper litho-unit IV.

Lithounit IV $(0-60 \mathrm{~cm})$ consists of crudely laminated silt with broad laminations of silt and fine sand. The upper $30 \mathrm{~cm}$ of the unit is reddish brown (5 YR 5/4) in colour and has distinct prismatic peds. Gypsum crystallites occur as evaporates found in the subsurface from groundwater. This unit represents drying of the playa surface, represented by a soil over playa sediments deposited while playa was shallow and saline. This lithounit grades into lithounit III.

Lithostratigraphy is summarized in table 2, indicates that lithounit IV is a pedogenically altered phase of lithounit III. Unit II is relatively rich in gypsum (surface as well as sub-surface) and unit I is sand dominated with alternations of silt with sub-surface gypsum. In the light of limited dates from the lower portion of the Bap-Malar playa, it is difficult to suggest a time bracket for the initiation of the playa. Nonetheless, if a sedimentation rate of $\sim 0.25 \mathrm{~mm} /$ year is assumed for the pre-15 ka BP lake sediments, the playa should have initiated around $25 \mathrm{ka}$. and its final drying certainly occurred later than $7 \mathrm{ka}$, probably around $6 \mathrm{ka}$.

\section{1b Mineralogy and geochemistry}

The XRD studies show a predominance of detrital minerals like quartz, feldspar, muscovite, and chlorite and evaporites like gypsum, halite, calcite and 
dolomite. An inverse relationship in proportions of gypsum and halite, and gypsum and calcite, exists. Thus, gypsum in samples from $0-120 \mathrm{~cm}$ depth of $\mathrm{W} 10$ is in trace amounts, while halite is predominant and calcite occurs in moderate amounts. Between 120 and $225 \mathrm{~cm}$ depth of W10, gypsum is dominant and halite and calcite are in minor amounts. A similar relationship of gypsum, halite and calcite is noticeable in samples from the K5 trench at the Kanod playa. Enzel et al (1999) examined gypsum concentrations in sediments from Lunkaransar playa and observed that a fresh water phase of perennial playa datable to 6.3 to $4.8 \mathrm{ka} \mathrm{BP}$ was practically devoid of gypsum. Presence and/or absence of gypsum was used by them to interpret lake hydrology and climate during the early to mid-Holocene. Gypsum-free sediments indicate a relatively wet/humid environment and gypsum-rich sediments indicate dry environmental conditions. However, nothing was mentioned about the relationship between gypsum and halite in Lunkaransar playa.

The inverse relationship in the Thar playas between halite and gypsum indicates that the playas remained saline from $15 \mathrm{ka} \mathrm{BP}$ to around 6 ka BP (in Bap-Malar) as sediments are either gypsum rich or halite rich. Observations by Deshmukh and Rai (1991) on the Sambhar, Kuchaman, Didwana playas in Rajasthan also suggest dry-wet phases based on the presence/absence of the evaporites (gypsum and halite). Gypsum in groundwater prevents precipitation of soda. Soda reacts with gypsum to form sodium sulphate and to some extent explains the inverse relationship between gypsum and halite. Sinha and Raymahashay (2000) have also recently reported similar observations while examining the absence of gypsum in near surface $(<1.5 \mathrm{~m})$ sediments of Sambhar salt lake in Rajasthan due to a low influx of calcium into the youngest lake sediments. Summarising, the evaporite minerals suggest that the Bap-Malar playa remained saline even during the so-called wetter climatic phase of the early to mid-Holocene.

\section{1c Pollen and carbon isotopes}

The W10 profile at Bap-Malar yielded microfossils only at a depth of $235-250 \mathrm{~cm}$ (figure 4). Most of the facies did not yield adequate pollen and spores except a broadly laminated silt of zone II. The pollen grains are represented by morphotypes belonging to chenopodiaceae, gramineae, cyperaceae, compositae, mimosae, rhamnaceae, etc. and spores are mostly of fungal origin. These microfossils by and large indicate local ponds and stagnant water-bodies in the rann proper and also in the surrounding regions. This is further supported by stable isotope analysis. In principle, use of stable carbon isotope for palaeoclimatic reconstruction is based on variation in ${ }^{13} \mathrm{C} /{ }^{12} \mathrm{C}$ ratios of $\mathrm{C} 3$ and C4 plants (Rajagopalan et al 1997). The C3 and $\mathrm{C} 4$ plants are separated on the basis of their photosynthetic pathways. C3 plants are predominant in humid environments with a mean $\delta^{13} \mathrm{C}$ value above $-26 \%$. C4 plants are abundant in tropical arid environments and have a mean $\delta^{13} \mathrm{C}$ value of about $-13 \%$. The stable carbon isotopic values on seven samples from W10 profile (w.r.t. P.D.B.) range from -15 to $-18 \%$ (table 1 ), over the last $15 \mathrm{ka}$ BP while climate changed during this period, it did not stray beyond the semi arid, and was never truly humid.

\section{1d Depositional environment}

While unraveling the depositional environments of playa sediments, attention has been paid to the relative proportions of the evaporite minerals (gypsum, halite and calcite) indicating significant changes in palaeohydrological conditions. Structural characters of sediments, degree of diagenesis and the presence or absence of evaporates formed on the surface and in subsurface sediments has also been taken into consideration. Drying episodes of the playa are indicated by moderate diagenesis of sediments in the upper part of unit IV $(0-30 \mathrm{~cm})$, by the development of gypsum crystals (selenites) across the bedding plane of silt fine-sand laminae in upper part of unit II $(180-220 \mathrm{~cm})$ and by weak pedogenesis of sandy laminae of unit I. Weak diagenesis is indicated by coating of powdery carbonate over sand grains. Drying of playa during unit IV is of longer duration as indicated by moderate diagenesis and is probably after $6 \mathrm{ka}$. This phase of drying needs to be precisely dated in future.

The perennial stage of the playa is represented by finely laminated silt and fine sand with low concentration of gypsum and a higher proportion of halite and calcite. Silt and fine sand laminae of unit II were deposited between $8 \mathrm{ka} \mathrm{BP}$ and $7 \mathrm{ka}$ $\mathrm{BP}$, around $11 \mathrm{ka} \mathrm{BP}$ and $>15 \mathrm{ka} \mathrm{BP}$ (at a depth of 5.2 to $5.3 \mathrm{~m}$ ). Though the playa was perennial with ground water above the surface, it was saline as indicated by the presence of calcite, halite and traces of gypsum crystallites. The perennial water playa of the early Holocene ( $8 \mathrm{ka} \mathrm{BP}$ and $7 \mathrm{ka} \mathrm{BP}$ ) was the most conspicuous hydrological change in Bap-Malar playa, which by and large remained saline and shallow with fluctuating ground water particularly at $15 \mathrm{ka} \mathrm{BP}$ and $11-10 \mathrm{ka} \mathrm{BP}$.

\subsection{Kanod playa}

Kanod playa $\left(27^{\circ} 08^{\prime} 14^{\prime \prime} \mathrm{N}, 71^{\circ} 14^{\prime} \mathrm{E}\right)$ is about $32 \mathrm{~km}^{2}$, a crescentic elongated depression (figures 1 
and 3), is located $35 \mathrm{~km}$ northeast of Jaisalmer in an area with mean annual rainfall of $160 \mathrm{~mm}$ and potential evapo-transpiration in excess of $2000 \mathrm{~mm} /$ a. Ephemeral channels cut through pediments surrounding the playa and drain into the playa. The playa surface remains practically dry throughout the year, except the monsoon months of August-September when occasional storm rains fill the playa with water up to about $0.5 \mathrm{~m}$. The mean annual winter rainfall is $\sim 30 \mathrm{~mm}$ and does not contribute effectively to surface runoff. The Kanod playa is thus dependent more on groundwater discharge (brine with a salinity $>25 \mathrm{~g} / \mathrm{l}$ ) than surface runoff during summer monsoons. Thus groundwater constitutes the major component of the hydrology of this playa.

Initial geomorphological observations by Anand Prakash (1980) indicated that the neo-tectonics was responsible for the formation of the Mithawala, Kanodwala and Khanowala ranns. During $1988-$ 1992, many pits were dug in saline lakes located at Kanod (2), Pokaran (6), Dediya (1), Zalaria (2) in Jaisalmer, and Thob (2) and Pachpadra (2) in Barmer districts. Basic stratigraphic and pollen preservation potential for the saline lakes at Kanod, Pokaran, Zalaria, Dediya are reported by Deotare and Kajale (2002) who attempted correlation of the stratigraphic sequences at Lunkaransar (Enzel et al 1999), Thob (Deotare and Kajale 1996) and Kanod (Deotare et al 2000). The blackish silty layer $(150-140 \mathrm{~cm})$ in Kanod yielded significant microfossils, and this is also found in playas at Lunkaransar and Thob. Initial pollen analysis on Kanod by Sharma and Chauhan (1991) with two conventional radiocarbon dates, on lake sediments of $8,701 \pm 198$ a BP $(180 \mathrm{~cm})$ and $9,567 \pm 159 \mathrm{a}$ BP $(250 \mathrm{~cm})$ suggested that the playa formed during the early Holocene.

\section{2a Sediments}

The particle size analysis of the representative samples from Kanod shows that the sediments are mainly dominated by sand and silt fraction with very little clay. Sediments from K5 are alkaline in nature with $\mathrm{pH}$ ranging from 7.8 to 8.3 . The distribution of calcium carbonate is erratic and does not show any specific trend. The organic carbon content $(0.8$ to $1.3 \%)$ is relatively high at $42-176 \mathrm{~cm}$ depth level as compared to lower and upper levels of the profile. The organic carbon content, which is one of the vital factors for the preservation of microfossils, is very low in Bap-Malar sediments as compared to Kanod, and may be one of the reasons for the better preservation of microfossils in Kanod playa. The AMS dates as well as $\delta^{13} \mathrm{C}$ analytical results for selected samples are given in table 3 .

\section{2b Lithostratigraphy}

The three pits (figure 3), at an average depth of $2.5 \mathrm{~m}$ below the present surface in the deeper portion of the playa, reveal the following five major lithounits (figure 5).

Lithounit I $(300-200 \mathrm{~cm})$ consists of reworked aeolian sand rich in silicate minerals (quartz and albite felspar), loose and probably rests unconformably on claystone of Jurassic age at a depth varying from 3 to $5 \mathrm{~m}$ below the surface of the playa (Deshmukh and Rai 1991). This unit has a gradational contact with overlying Unit II $(200-150 \mathrm{~cm})$ dominated by gypsum sand with fine intercalations of silt laminae, particularly between 170 and $150 \mathrm{~cm}$. This lithounit has yielded pollen grains (figure 5) and has been dated to around $9 \mathrm{ka}$ BP (table 3). The lithounit II also has a gradational contact with lithounit III $(150-140 \mathrm{~cm})$ which is finely laminated (5Y7/1) polleniferous silt with specks of charcoal. Gypsum is not obvious in field exposures, but present in traces as revealed by XRD analysis. The lithounit III is capped by lithounit IV $(140-20 \mathrm{~cm})$ consisting of bioturbated, broadly laminated brownish grey silt with fine intercalations of gypsum sand laminae and has also yielded pollen grains. The lithounit IV is capped sharply by lithounit V $(20-0 \mathrm{~cm})$ consisting of a hard gypsum layer $(20-10 \mathrm{~cm})$ and by loosely packed yellowish brown sandy silt.

A summary of the lithostratigraphy and its interpretation is presented in table 4 .

\section{2c Mineralogy}

The XRD pattern on the samples from the K5 profile shows the presence of aragonite, calcite, gypsum, felspar, halite, muscovite and quartz. Quartz is present in a relatively significant amount in upper and lowermost samples, thereby indicating nearby dunes as a source of the sediments at the respective depth of 5-10 and 205-250 cms. Gypsum is present at a lower level (176 to $250 \mathrm{~cm}$ ) while halite is present in upper levels ( 5 to $148 \mathrm{~cm}$ ), indicating the saline nature of the sediment throughout.

AMS ${ }^{14} \mathrm{C}$ dates (table 3 ) suggest that the playa originated during the Pleistocene-Holocene transitional climatic phase. The playa was semi-perennial to ephemeral between 7.5 and $5.8 \mathrm{ka}$ and was desiccated completely after $5.5 \mathrm{ka}$ as revealed by a $10 \mathrm{~cm}$ thick hardened gypsum layer between 10 and $20 \mathrm{~cm}$.

The $\delta^{13} \mathrm{C}$ values range from -14.7 per mil to -16.2 per mil for the last 9.4 ka suggesting predominance of $\mathrm{C} 4$ plants, mainly grasses, adapted to a 


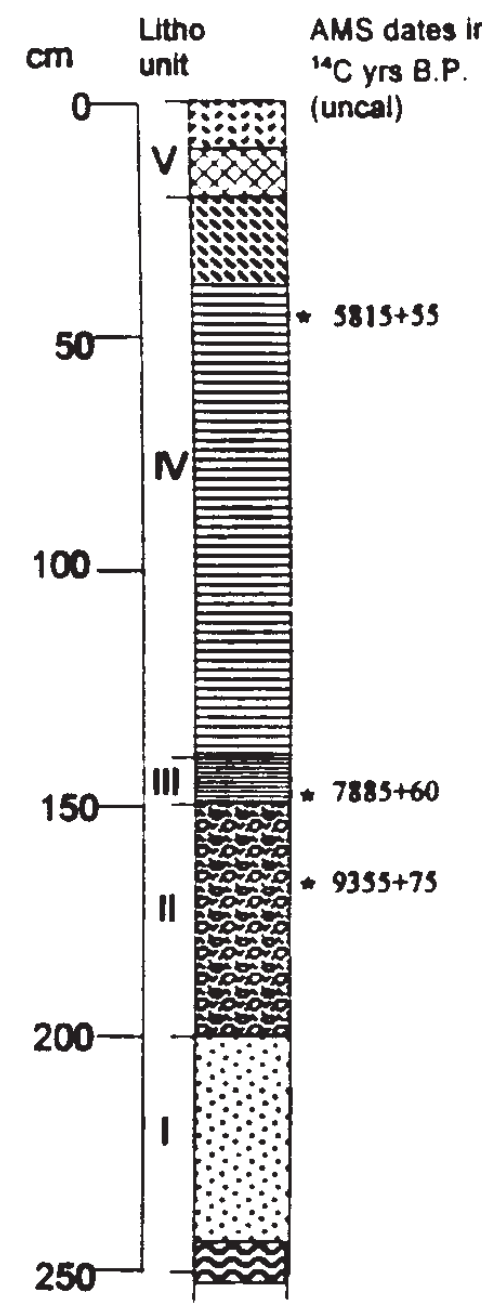

\section{Cyperaceae \% Cheno/Amr \% Typhaceae \%}
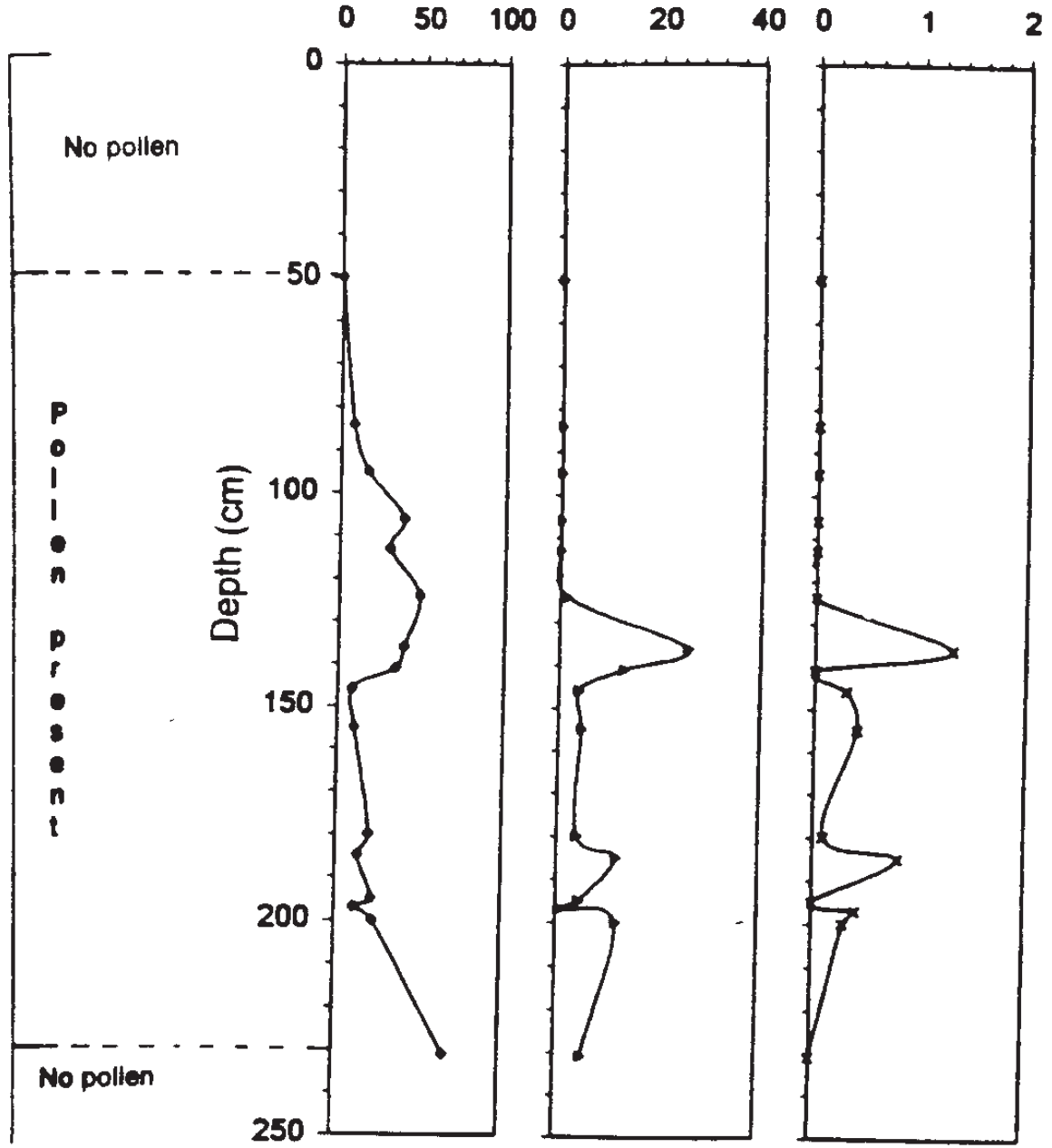

\section{Stratigraphic details of K5 trench .}

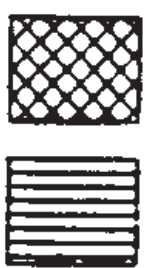

Laminated clayey

silt with selenite

Broadly laminated silt

with gypsum sand laminae

$\because \because \because 2$

Reworked aeolian sand

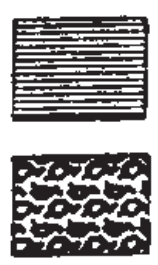

Finely laminated silt

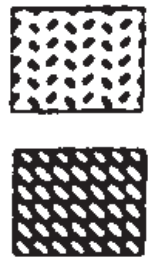

Sandy silt

Gypsum sand with silt laminae
Bioturbated

limonitised silt

Under water

Figure 5. (Continued on facing page)

semi arid environment. Pollen and spores in litho units II, III and IV consist primarily of cyperaceae, chenopodiaceae amaranthaceae, gramineae, pinaceae, typhaceae etc (figure 5) indicating the dominance of grasses, sedges, and amaranthes in the region around the Kanod lake. Presence of evaporites in units II to IV suggests that Kanod playa remained mostly saline throughout the early to mid-Holocene.

Briefly, the Kanod playa (table 5), in comparison with Bap-Malar shows better preservation of pollen for reasons not yet properly understood, as sediments are primarily saline, organically moderate and alkaline in both the cases. 


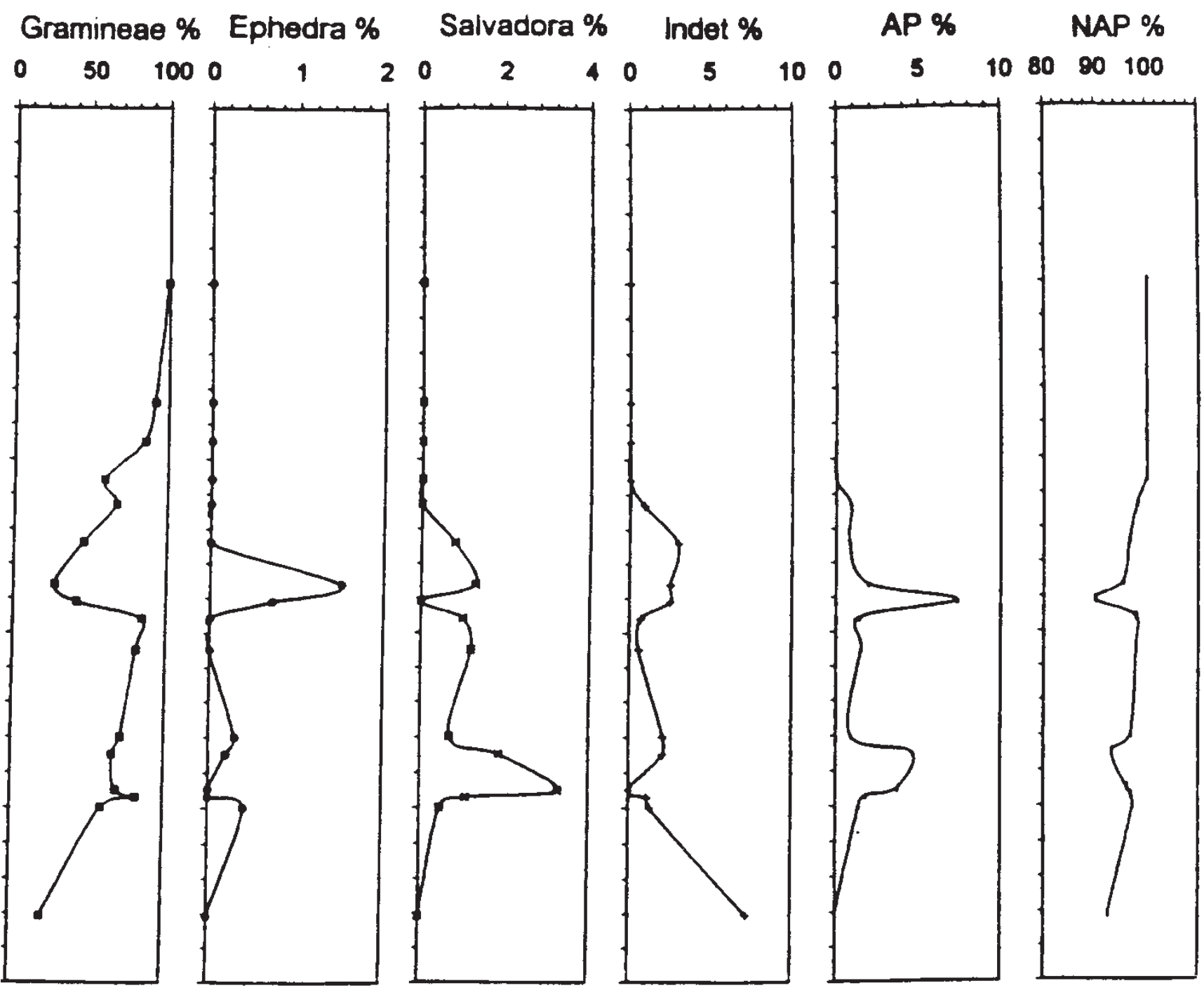

Figure 5. Pollen distribution in K5 trench of Kanod playa.

Table 3. AMS radiocarbon dates and $\delta^{13} C$ on the deposits from Kanod playa.

\begin{tabular}{cccccccl}
\hline $\begin{array}{c}\text { Sr. } \\
\text { no }\end{array}$ & Trench & $\begin{array}{c}\text { Sample } \\
\text { no. }\end{array}$ & Depth cm & Lab code & $\delta^{13} \mathrm{C}$ & $\begin{array}{c}{ }^{14} \mathrm{C} \text { age } \\
(\mathrm{aBP})\end{array}$ & $\begin{array}{c}\text { Calibrated age } \\
(1 \sigma)\left({ }^{14} \mathrm{Ca} \mathrm{BP}\right)\end{array}$ \\
\hline 1 & $\mathrm{~K} 1$ & $\mathrm{~K} 1 / 22$ & $140-145$ & $\mathrm{~V} 14184$ & -16.195 & $7885 \pm 60$ & 8940 to 8550 \\
2 & $\mathrm{~K} 1$ & $\mathrm{~K} 1 / 23$ & $40-45$ & $\mathrm{~V} 14188$ & -14.701 & $5815 \pm 55$ & 6720 to 6540 \\
3 & $\mathrm{~K} 2$ & $\mathrm{~K} 2 / 24$ & $160-162$ & $\mathrm{~V} 141898$ & -14.833 & $9355 \pm 75$ & 10389 to 10215 \\
4 & $\mathrm{~K} 2$ & $\mathrm{~K} 2 / 25$ & $120-125$ & $\mathrm{~V} 14190$ & -16.192 & $9030 \pm 65$ & 10035 to 9960 \\
\hline
\end{tabular}

\section{Geoarchaeology of playas}

In order to understand human response to environmental changes as inferred from the playa sediments, reconnaissance survey of regions surrounding playas was carried out. Sites ranging in age from late Acheulian to early Historic have been discovered around Bap-Malar (figure 6) and Kanod playa (figure 7) and their geomorphic context and approximate ages are given in table 6 .

In general, these sites are more or less surface sites, either on stable dunes or pediments with thin rubble regolith. Only at Bari Bavri has archaeological material been discovered in stratified fluvial deposits of an ephemeral shallow 
Table 4. Lithostratigraphy and palaeoenvironment of Kanod playa.

\begin{tabular}{|c|c|c|c|}
\hline $\begin{array}{l}\text { Litho } \\
\text { unit }\end{array}$ & Depth cm & Character & $\begin{array}{l}\text { Approx. age/ } \\
\text { environment }\end{array}$ \\
\hline I & $\begin{array}{c}>300 \\
300-200\end{array}$ & $\begin{array}{l}\text { Claystone } \\
\text { Reworked aeolian quartz sand. Pollen } \\
\text { present }\end{array}$ & $\begin{array}{l}\text { Mesozoic } \\
\text { Terminal Pleistocene (?) }\end{array}$ \\
\hline II & $200-150$ & $\begin{array}{l}\text { Gypsum sand with fine intercalations of } \\
\text { grayish silt. Pollen present }\end{array}$ & $\begin{array}{l}\text { Early Holocene (basal) } \\
(\sim 9 \text { ka). Shallow ephe- } \\
\text { meral lake }\end{array}$ \\
\hline III & $150-140$ & $\begin{array}{l}\text { Finely laminated grayish silt with pollen } \\
\text { and specks of charcoal, without prominent } \\
\text { gypsum. }\end{array}$ & $\begin{array}{l}\text { Early Holocene }(\sim 7.8 \mathrm{ka}) \\
\text { Lake full phase }\end{array}$ \\
\hline IV & $140-20$ & $\begin{array}{l}\text { Bioturbated, mottled, thickly laminated } \\
\text { brownish gray silt with intercalated gyp- } \\
\text { sum, and pollen. }\end{array}$ & $\begin{array}{l}\text { Early to mid Holocene. } \\
\text { Shallow lake, seasonal with } \\
\text { occasional lake full stage }\end{array}$ \\
\hline $\mathrm{V}$ & $20-0$ & $\begin{array}{l}\text { Hard gypsum capped by yellowish brown } \\
\text { sandy silt }\end{array}$ & $\begin{array}{l}\text { Mid to Late Holocene } \\
(<5.5 \mathrm{ka}) . \text { Lake dry phase }\end{array}$ \\
\hline
\end{tabular}

Table 5. Comparison between Bap-Malar and Kanod playas.

\begin{tabular}{|c|c|c|c|}
\hline Sr. No & Parameter & Bap-Malar & Kanod \\
\hline 1 & Area in $\mathrm{km}^{2}$ & 78 & 32 \\
\hline 2 & Annual rainfall & $200 \mathrm{~mm}$ & $160 \mathrm{~mm}$ \\
\hline 3 & Evapo-transpiration & c. $2000 \mathrm{~mm}$ & $>1500 \mathrm{~mm}$ \\
\hline 4 & Hill slopes & Not prominent & Prominent \\
\hline 5 & $\begin{array}{l}\text { Topography } \\
\text { Height variation }\end{array}$ & $\begin{array}{l}\text { Gentle } \\
209-187 \mathrm{~m}\end{array}$ & $\begin{array}{l}\text { Steep } \\
180-140 \mathrm{~m}\end{array}$ \\
\hline 6 & Basin type & Shallow & Steep sided \\
\hline 7 & Maximum depth & $5-7 \mathrm{~m}$ & $\begin{array}{l}2.5 \mathrm{~m} \text { exposed only (due to } \\
\text { high water table) }\end{array}$ \\
\hline 8 & $\begin{array}{l}\text { Texture of playa } \\
\text { sediments }\end{array}$ & Sand prominent & Silt prominent \\
\hline 9 & Organic carbon content & Overall low & Relatively high \\
\hline 10 & Evaporite composition & $\begin{array}{l}\text { Gypsum and halite, } \\
\text { inversely related }\end{array}$ & $\begin{array}{l}\text { Gypsum and halite } \\
\text { inversely related }\end{array}$ \\
\hline 11 & Plant fragments & Rare & Prominent, specks \\
\hline 12 & Pollen preservation & Poor & Relatively good \\
\hline 13 & Beginning of playa & $>15$ ka (LGM) & c. $12 \mathrm{ka}$ \\
\hline 14 & Lake full stage & 8-7 ka (early Holocene) & 8-7 ka (early Holocene) \\
\hline 15 & Lake drying phase & $\sim 6 \mathrm{ka}$ & $\sim 5.5 \mathrm{ka}$ \\
\hline 16 & Lake water condition & Saline throughout & Saline throughout \\
\hline 17 & Archaeology around playa & $\begin{array}{l}\text { Microliths on stable dunes } \\
\text { with pottery and bones }\end{array}$ & $\begin{array}{l}\text { Microliths on pediments mostly } \\
\text { without pottery and bones }\end{array}$ \\
\hline
\end{tabular}

channel. On the basis of the period ranging from late Acheulian to early Historic, a few representative sites like Lordiya, Jamba and Bari Bavri have been selected and are described in detail.

\subsection{Lordiya}

The site of Lordiya is situated on Jodhpur highway, about $3 \mathrm{~km}$ east of Phalodi in Jodhpur district. It is located on the left bank of a dry stream with 3-4 m 


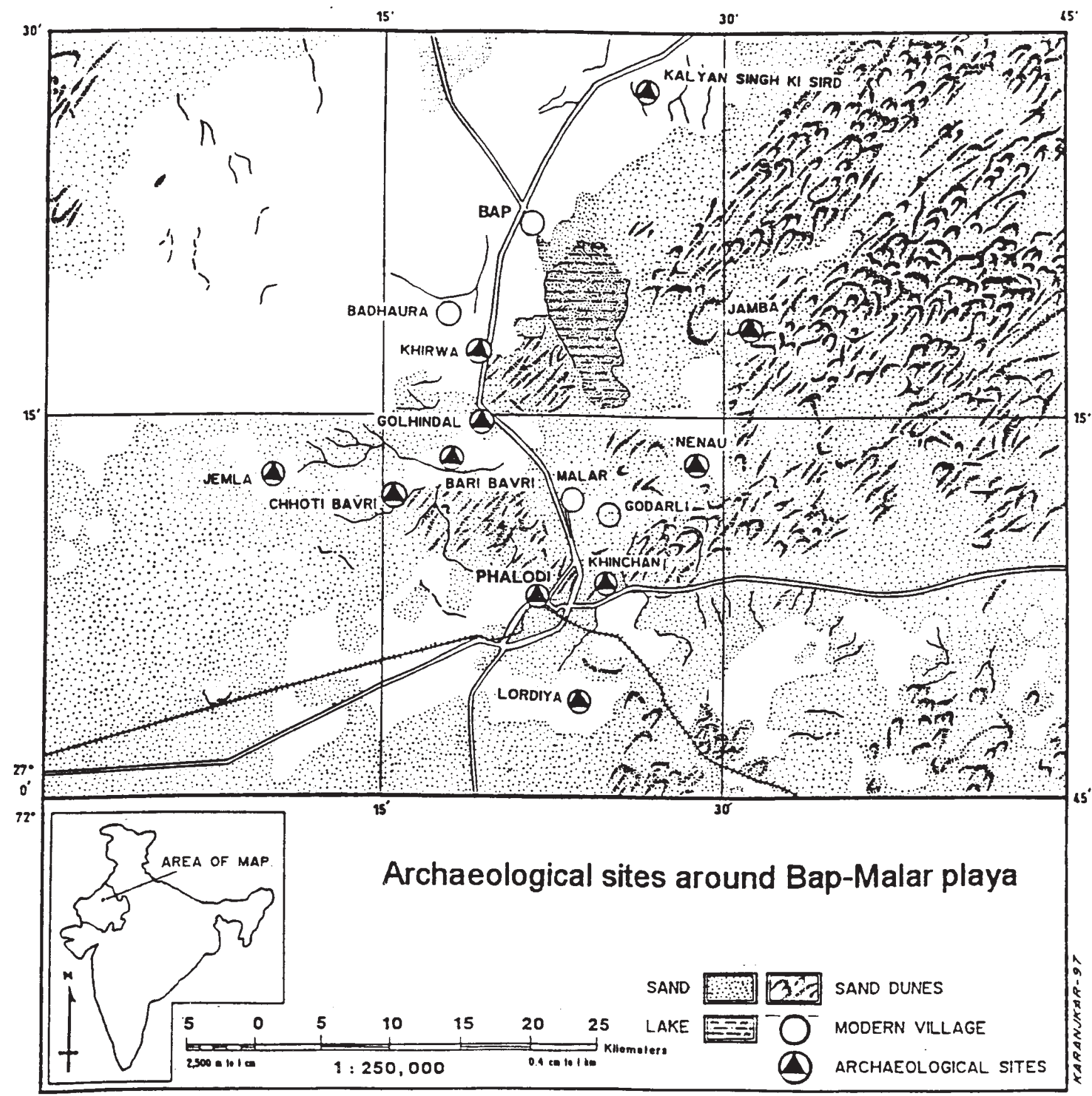

Figure 6. Archaeological sites around Bap-Malar playa.

high banks developed in a siliceous limestone. The stream is presently choked by dune sands and was probably a southeasterly feeder to the Bap-Malar playa. The limestone valley cliff is disconformably capped by $2.5 \mathrm{~m}$ thick limestone rubble which is affected by karstic weathering as indicated by solution cavities filled with brown (7.5YR 3/4) loam in the lower part. The upper most part of the regolith consists of $30-40 \mathrm{~cm}$ thick pebbly cobbly gravel consisting of patinated quartzite, limestone and sandstone within a matrix of ferruginous granules and brownish calcareous loam (figure 8).
The most noteworthy artefact, found in the upper part of the regolith from Lordiya, is an ovate shaped handaxe (figure 9), with the dimensions $11.5 \mathrm{~cm} \times 7.5 \mathrm{~cm} \times 3.0 \mathrm{~cm}$. It is made on quartzitic sandstone with a dark reddish brown (5YR3/4) patina on its upper and lower surfaces. The flake scars are sharp without any sign of wind blasting and the artefact has not suffered long distance transport. On a techno-typological basis, the handaxe is of late Acheulian tradition. In addition many middle and upper Palaeolithic flakes on quartzitic sandstone and chert were also found in 


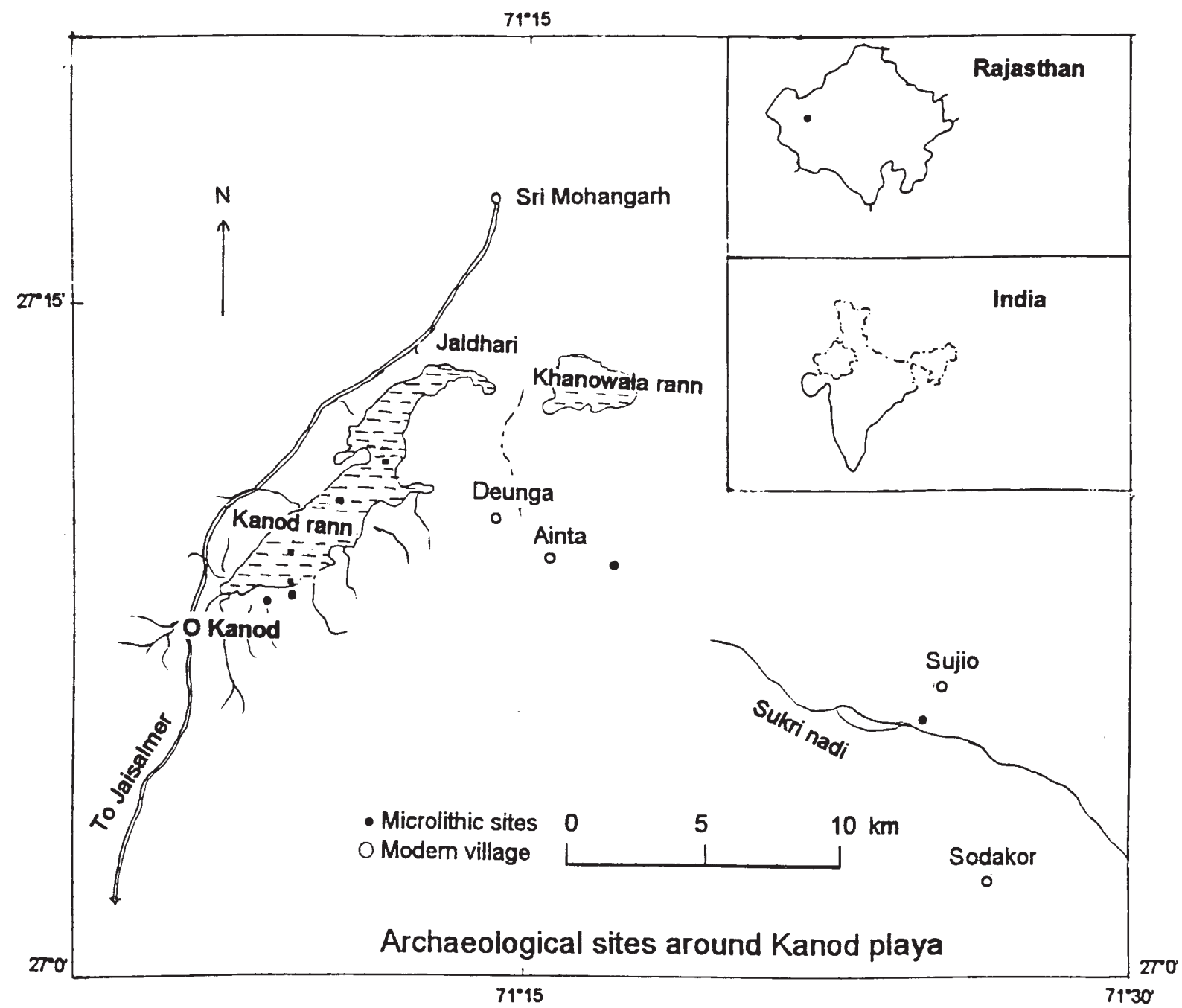

Figure 7. Archaeological sites around Kanod playa.

Table 6. Archaeological sites and their geomorphic settings.

\begin{tabular}{|c|c|c|c|c|}
\hline $\begin{array}{l}\text { Sr. } \\
\text { no. }\end{array}$ & $\begin{array}{l}\text { Location (latitude } \\
\text { and longitude) }\end{array}$ & Landscape context & $\begin{array}{c}\text { Probable } \\
\text { environment }\end{array}$ & $\begin{array}{l}\text { Cultural material and } \\
\text { approximate age }\end{array}$ \\
\hline 1 & $\begin{array}{l}\text { Lordiya } \\
\left(27^{\circ} 06^{\prime} \mathrm{N} ; 72^{\circ} 23^{\prime} \mathrm{E}\right), \\
\text { (Dist. Jodhpur) }\end{array}$ & $\begin{array}{l}\text { Dry stream banks and } \\
2.5 \mathrm{~m} \text { thick rubble } \\
\text { regolith }\end{array}$ & $\begin{array}{l}\text { Arid to semi- } \\
\text { arid }\end{array}$ & $\begin{array}{l}\text { Late Acheulian handaxe, } \\
\text { middle, upper Palaeolithic } \\
\text { flakes (late Pleistocene) }\end{array}$ \\
\hline 2 & $\begin{array}{l}\text { Jamba } \\
\left(27^{\circ} 18^{\prime} \mathrm{N} ; 72^{\circ} 31^{\prime} \mathrm{E}\right) \\
\text { (Dist. Jodhpur) }\end{array}$ & Stable dune surface & Relatively wet & $\begin{array}{l}\text { Microliths with or without } \\
\text { pottery (early Holocene) }\end{array}$ \\
\hline 3 & $\begin{array}{l}\text { Kanod playa } \\
\left(27^{\circ} 08^{\prime} \mathrm{N} ; 71^{\circ} 14^{\prime} \mathrm{E}\right) \\
\text { (Dist. Jaisalmer) }\end{array}$ & $\begin{array}{l}\text { Pediment on limestone } \\
\text { with thin regolith }\end{array}$ & Relatively wet & $\begin{array}{l}\text { Microliths without pottery } \\
\text { (early Holocene) }\end{array}$ \\
\hline 4 & $\begin{array}{l}\text { Bari Bavri } \\
\left(27^{\circ} 13^{\prime} \mathrm{N} ; 72^{\circ} 18^{\prime} \mathrm{E}\right) \\
\text { (Dist. Jodhpur) }\end{array}$ & $\begin{array}{l}\text { Ephemeral stream chan- } \\
\text { nel gravel }\end{array}$ & Relatively dry & $\begin{array}{l}\text { Upper Palaeolithic flakes, } \\
\text { early Historic pottery, } \\
\text { hearth and large brick }\end{array}$ \\
\hline 5 & $\begin{array}{l}\text { Mohangarh, } \\
\left(27^{\circ} 17^{\prime} \mathrm{N} ; 71^{\circ} 15^{\prime} \mathrm{E}\right) \\
\text { (Dist. Jaisalmer) }\end{array}$ & $\begin{array}{l}\text { Pediment, sandsheet, } \\
\text { dry stream channel }\end{array}$ & Relatively dry & $\begin{array}{l}\text { Microliths, early Historic } \\
\text { pottery and brick (early to } \\
\text { late Holocene) }\end{array}$ \\
\hline
\end{tabular}




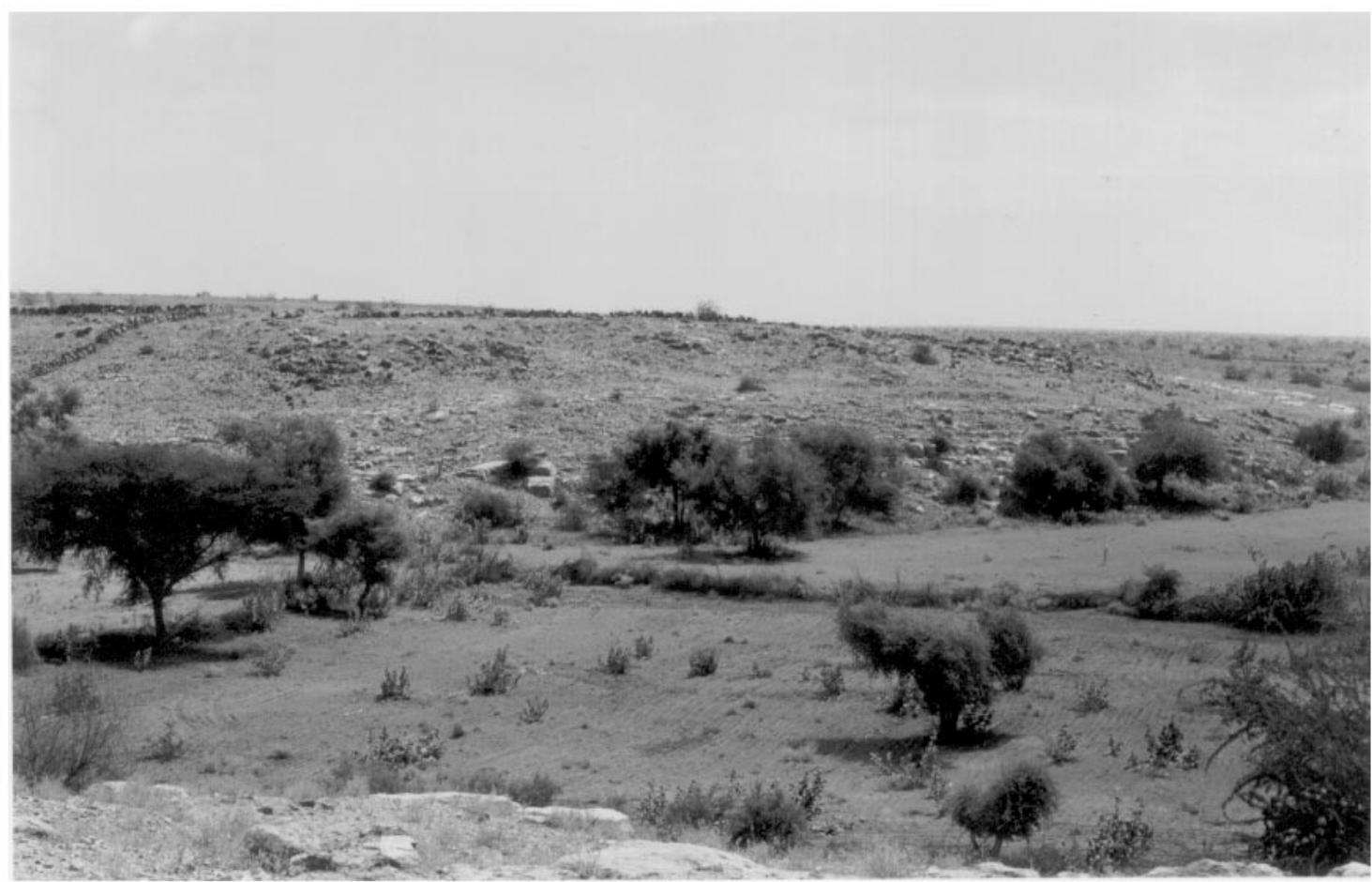

Figure 8. General view of Acheulian site of Lordiya.

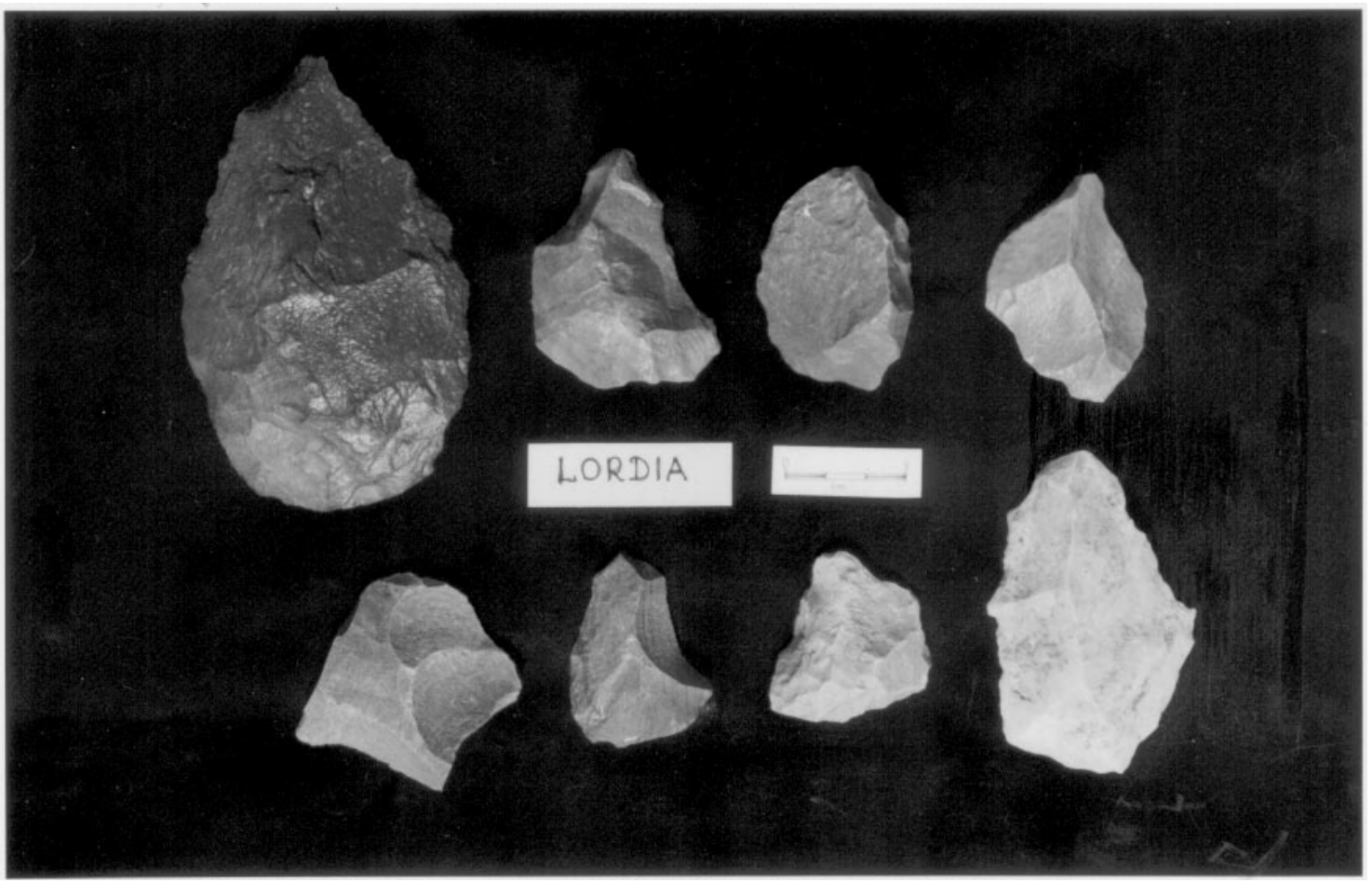

Figure 9. Late Acheulian hand axe and other flake tools from Lordiya.

the uppermost part of the regolith. Of these, two flakes of upper Palaeolithic cultural tradition are almost fresh without any sign of wind blasting and desert varnish. Other flakes, however, have surfaces with wind blasting but without any desert varnish (figure 9).
Such observations on the state of surface modifications of stone artefacts recovered from the uppermost $30-40 \mathrm{~cm}$ of regolith indicate that palaeolithic hunter-gatherers occupied the valley pediments since the early late Pleistocene. The karstic weathering, with slight development of brownish 
loam in the lower part of the regolith, indicates relatively less arid climate, when the stream was flowing and the Stone Age hunter-gatherers were in the region. The artefacts were incorporated in the gravel deposited during short lived floods characteristic of arid climate. It is proposed to undertake detailed geoarchaeological study of Lordiya and surrounding area. Such a study will add new information on Stone Age cultures in the context of evolutionary history of the stream, now totally defunct and choked by aeolian sands.

\subsection{Jamba}

A rich scatter of microlithic artefacts with potsherds and bone fragments were discovered on a stabilized surface of dunes developed about $6 \mathrm{~km}$ west of Bap-Malar playa (figure 10). Microliths are made on chalcedony, chert and quartz and consist of flakes with or without retouches, fluted cores on nodules and flakes, and varieties of scrapers, points and blades (figure 11). The pottery found along with microliths is non-diagnostic for any particular cultural tradition. The animal bones are fragmentary and partially mineralized and the fluorine/phosphate ratio of the bones gave values within 1-2, thereby indicating an early- mid Holocene age of the microliths (Deotare et al 1998). A luminescence age of $\sim 7 \mathrm{ka}$ was obtained just below microliths in dune sand at $1 \mathrm{~m}$. Sand layer at the depth of $1 \mathrm{~m}$ from the surface gave an age of $11 \mathrm{ka}$. For comparison, fluorine/phosphate ratio and preliminary luminescence age indicate an early Holocene $(\sim 7 \mathrm{ka} \mathrm{BP})$ age of the microlithic site at Jamba. Dune stabilization, human activity over the stabilized dune surface, and the lake full phase of the Bap-Malar playa are probably coeval events. Similar evidence is preserved on other dune sites at Gol Hindal, Nenau, Khinchan, Khirwa, Jemla in the vicinity of Bap-Malar playa (figure 6).

A rich microlithic site is located on the southern edge of Kanod playa. Microliths occur in a regolith covering a pediment developed over yellowish limestone interbedded with sandstone. Microliths are made on chert and quartz, and there is no pottery.

Recently Biagi and Veesar (1998-99) have discovered microliths and pottery on stable dune surfaces bordering playas near Thari town in upper Sindh of the Thar desert in Pakistan. The investigators have not been able to date these sites precisely. On typo-technological grounds, it has been argued that the dunes were occupied since the terminal Pleistocene. The discovery of Kot Diji pottery on these dunes opens up new avenues of research in early Holocene human ecology of the arid core of the Thar desert.

\subsection{Bari Bavri}

This site is located on the right bank of an ephemeral channel draining into the Bap-Malar playa (figure 6). Large numbers of potsherds were found scattered on the surface of a cobbly pebbly gravelly channel, about $1.5 \mathrm{~km}$ wide and without any conspicuous banks (figure 12). Most potsherds are red in colour with and without painting of black on red. A few sherds have a design of a fishlike figure near the bowl neck of black on red ware (figure 13).

A small trench $(2 \mathrm{~m} \times 2 \mathrm{~m})$ was dug in the central part of the site. It revealed a $1.2 \mathrm{~cm}$ thick habitation deposit from the surface of the channel with an intact hearth with large amount of charcoal fragments in a pebbly sandy gravel between 90 and $70 \mathrm{~cm}$ depth from the surface. Just outside the trial trench a well-baked brick $(37 \times 25 \times 7 \mathrm{~cm})$ was also found. The channel gravel rests unconformably on bedrock (sandstone) at a depth of $1.8 \mathrm{~m}$ below the surface.

Though it was difficult to date the site on the basis of pottery (due to non-diagnostic features), the technology and the size of the brick indicates that the human activity in the channel of the Bari Bavri was during the early historic period. Three conventional ${ }^{14} \mathrm{C}$ dates (table 7 ) on charcoal in the hearth confirm the approximate archaeological dating of the site.

It was necessary to understand the nature of the preservation of an intact hearth, a well-baked brick and un-abraded potsherds of late Gupta period ( $\sim 500$ A.D.) in the sandy/gravelly channel of the Bari Bavri. It appears that the high width/depth ratio of the channel reduced erosive capacity during high intensity floods. Wells (1980) has conducted a detailed study of ephemeral streams in the alluvial fans of arid southwestern USA and has observed that the scouring activity of a stream during a flood is insignificant in a wide sandy gravelly channel with a small catchment area. The armouring effect of cobbles and pebbles in a sandy gravelly channel has also been observed by Deodhar and Kale (1999) in allochthonous streams in upland western Maharashtra. Similar results have also been observed by Schick (1980) in ephemeral streams of arid parts of southern Negev, Israel. It is quite likely that the time period between subsequent flood events may be long enough for the preservation of archaeological objects with minimal disturbance.

The alluvial fill about $2 \mathrm{~km}$ downstream of the archaeological site occurs in a slightly narrow and incised bedrock valley. This fill contains abraded potsherds derived from the site in the upstream area. This fill is later than the channel aggradation described above. The aggradation took place probably due to blocking of the channel by aeolian sand 


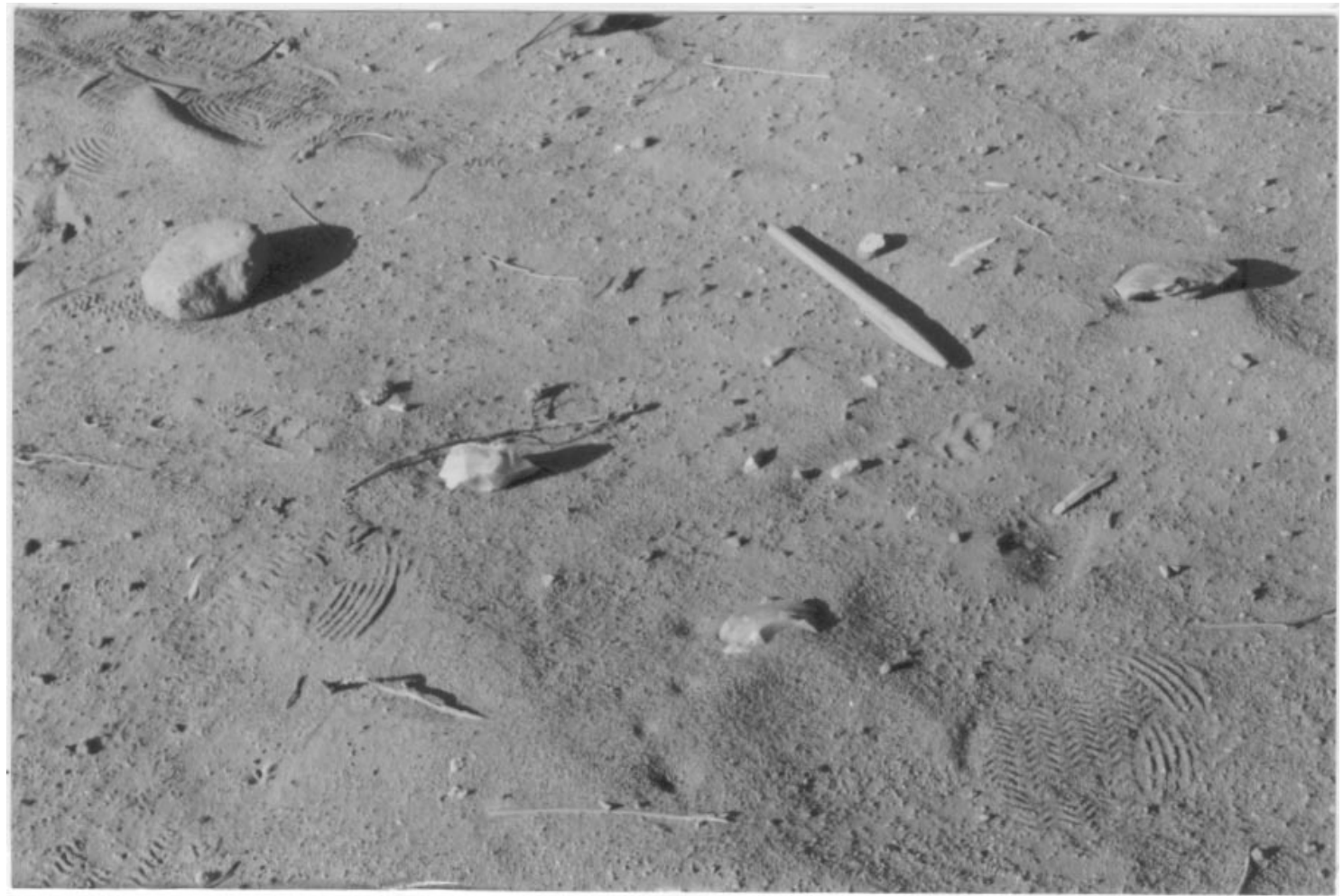

Figure 10. Spread of microliths on the stable dune surface at Jamba.

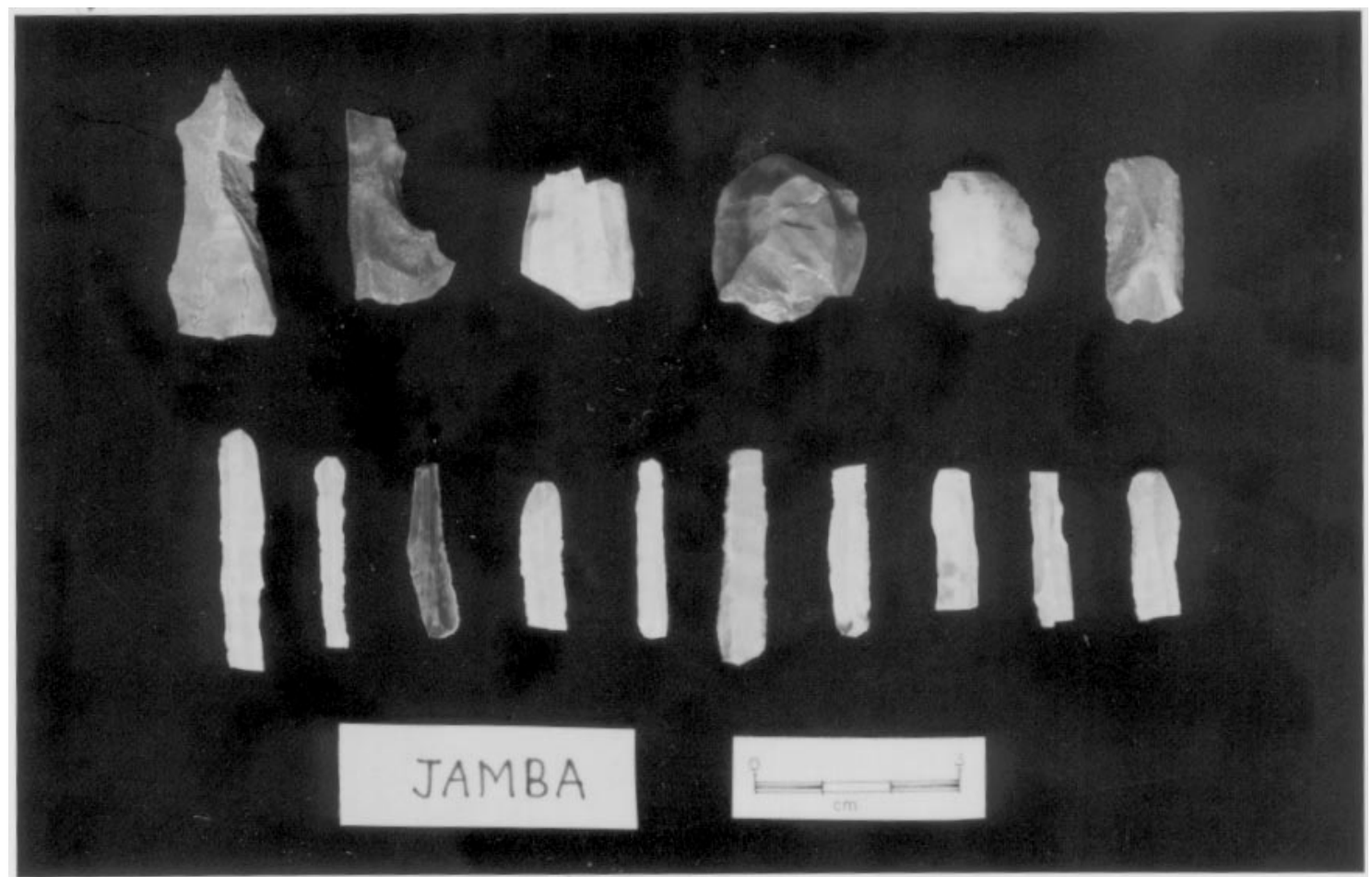

Figure 11. Microlithic cores and blades from Jamba.

further downstream towards Bap-Malar playa. The geomorphological, geochronological and geoarchaeological studies in surrounding areas of the playa and also near Khara-Bikampur, $30 \mathrm{~km}$ northwest of Bap show that there are two generations of dune sand/sandsheet activity. The older and higher aeolian sands are stabilised, at times occupied by Mesolithic pastoralists during the early-mid 


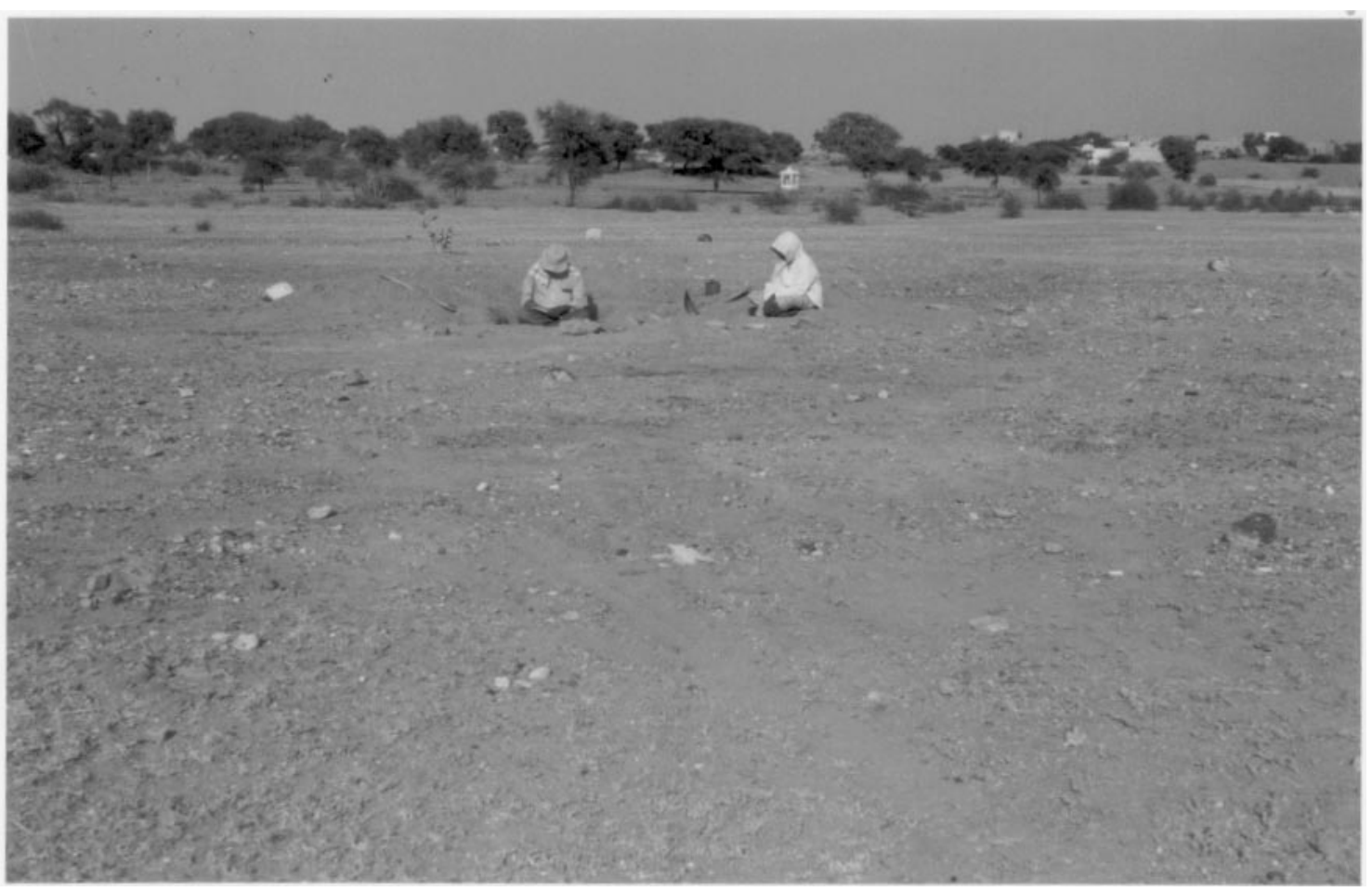

Figure 12. General view of Bari Bavri channel gravel site with excavation pit in foreground.

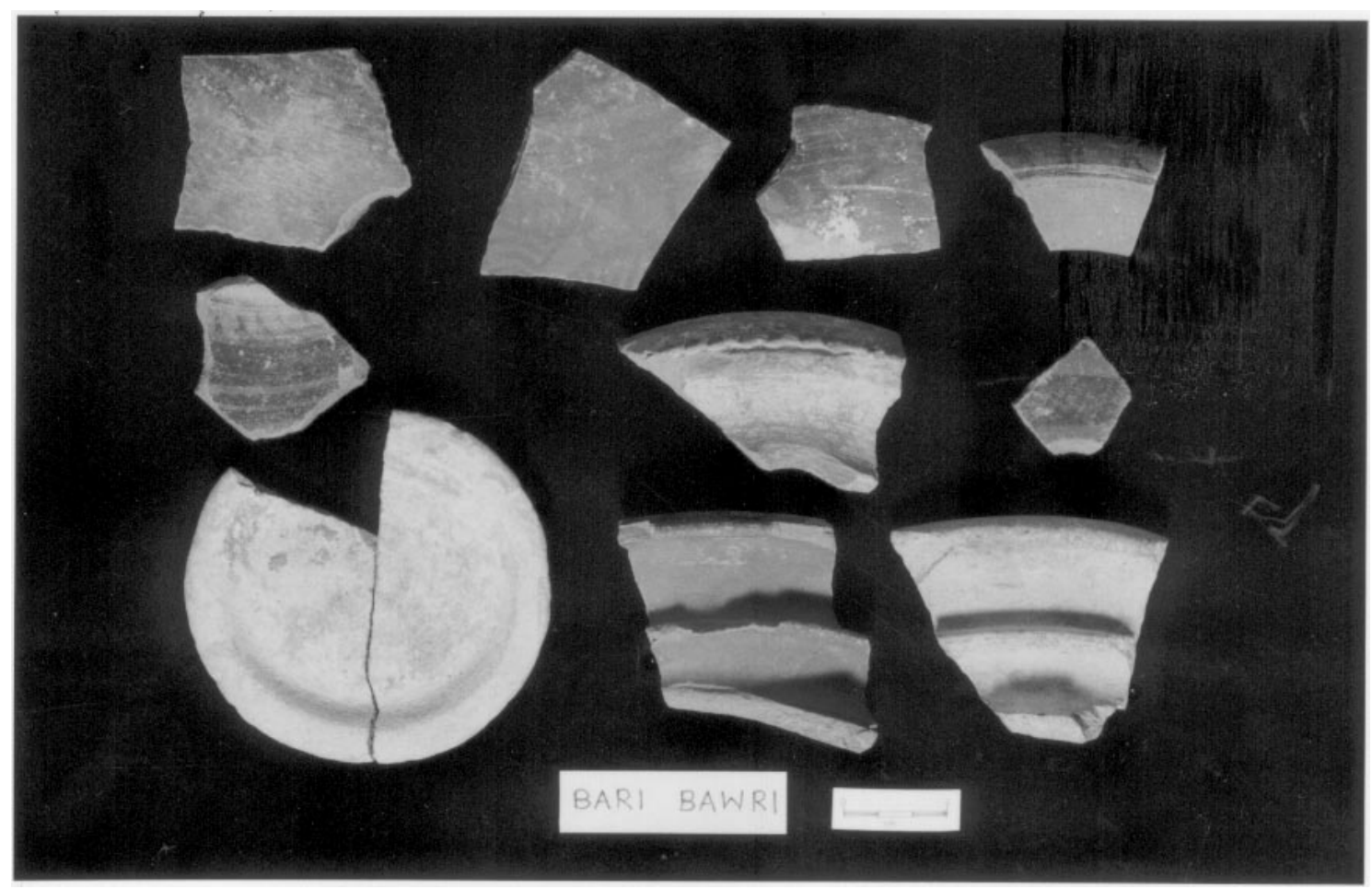

Figure 13. Close-up of painted pottery from Bari Bavri.

Holocene $(\sim 7-5 \mathrm{ka})$. The younger dunes are $\leq 2 \mathrm{ka}$ and later. The last phase of major dune development has occurred around 600a to 700a in the Thar desert (Kar et al 1998). It is therefore, quite likely that the fill containing late Gupta potsherds might have been formed as a result of blocking of the stream during the major aeolian activity assignable to $>600-700 \mathrm{aBP}$.

The geoarchaeological studies at Bari Bavri suggests that the preservation of a late Gupta 
Table 7. Dates from Bari Bavri.

\begin{tabular}{ccc}
\hline Lab. no. & Depth in cm & $\begin{array}{c}\text { Radiocarbon } \\
\text { date BP }\end{array}$ \\
\hline PRL-2030 & $10-15$ & $1490 \pm 85$ \\
PRL-2031 & $20-30$ & $1400 \pm 95$ \\
PRL-2032 & $70-75$ & $1490 \pm 95$ \\
\hline
\end{tabular}

settlement in an ephemeral sandy channel was partly due to hydrological factors as mentioned above and partly due to long intervals between flood events. The latter aspect could possibly be due to increased aridity. Recently Kale et al (1997) have observed a reduction in flood activity of the river Narmada in the sub-humid part of central India after the 5th century AD. These two examples of reduced flood activity in Narmada valley and at the Bari Bavri in western Rajasthan are from different climatic settings. These geomorphic features to some extent at least indicate environmental degradation around 5th century AD.

The preliminary geoarchaeological studies show that the arid core of the Thar witnessed a significant increase in human pastoral activity during the early Holocene when the playas were full of water and aeolian activity was weak. The aridity after 4000 aBP probably affected human activity, which increased marginally around $2-1.5 \mathrm{ka}$ BP in response to slight amelioration of climate.

\section{Conclusions}

The Bap-Malar and Kanod playas in the arid core of the Thar desert are primarily dependent on groundwater discharge unlike many other playas in arid parts of the world where there is significant allochthonous surface water from a catchment. On the whole they remained saline throughout their existence from $>15 \mathrm{ka}$ to the mid-Holocene $(\sim 5.5 \mathrm{ka})$. Both these playas dried up almost 1000 years earlier than the playas at Didwana and Sambhar in the semi-arid eastern margin of the Thar. The pollen morphotypes cyperaceae, chenopodicaceae/amaranthaceae, gramineae, ephedraceae, along with the presence of the evaporite minerals gypsum and halite throughout the existence of the playas support the view that the arid core of the Thar remained semi-arid to arid from the end Pleistocene to the mid-Holocene. The stable isotopic values also point towards a dominance of $\mathrm{C} 4$ plants (short grassland on the periphery of the playas), and therefore a semi arid climate since $\sim 15 \mathrm{ka}$ BP.

In the arid, western margin of the Thar, prolonged aridity with short duration episodes of relatively wet, yet semi-arid, climatic phases provided ecosystem conducive only for the pastoral life for prehistoric and early Historic communities since the LGM. The evidence from Lordiya points towards scant activity of upper Palaeolithic hunter-gatherers during the last Glacial arid climatic phase (Misra and Rajaguru 1989). On the other hand, prolific activity of Mesolithic pastoralists is preserved on stabilised dune surfaces bordering these playas, which were full of water during the early Holocene $(\sim 7-6$ ka BP $)$. The pastoral life somehow continued in the area even during the late Holocene when the playas were almost dry, intermittently getting filled with water from the ephemeral feeder streams. The well preserved site of Bari-Bavri occurring within wide $(1.5 \mathrm{~km})$ gravelly channel of the feeder stream of the Bap-Malar playa clearly show that when saline playas were an inhospitable environment, the feeder stream provided fresh water source for pastoralists, at least temporarily.

It is thus considered that the playas in arid core of the Thar are influenced more by local environmental factors rather than global climatic fluctuations. High resolution studies including AMS ${ }^{14} \mathrm{C}$ dating, stable isotopes, mineral magnetics are needed, and detailed geoarchaeological investigations of Mesolithic and early Historic sites will provide a new perspective of cultural ecology in the arid core of the Thar.

\section{Acknowledgements}

The present review has been possible essentially because of basic field data and multiple laboratory results generated and processed over a decade (1988-2000), kind support for which was initially provided by the then Deccan College authorities (1988-1993) and subsequently by the Department of Science and Technology, New Delhi (1995-1999). The major work of our group was confined to Bap-Malar and Kanod playas located in western Rajasthan and this paper is the outcome of investigations of the DST sponsored projects No. ESS/CA/A3-08/92 and ESS/CA/A3-12/94. The authors (B C D, M D K and S N R) are grateful to the authorities of the DST, New Delhi for their prompt financial assistance. We are also thankful to the then authorities and the staff of the Deccan College who helped us during the execution of these projects.

\section{References}

Achuthan H 1999 Micromorphology and Geochemistry of late Neogene-early Quaternary Ferricretes Jaisalmer Basin Rajasthan; Man and Environment 14(1) 77-90

Anand Prakash 1980 A study of landforms near Jaisalmer; Geophytology 10(1) 37-44 
Biagi P and Veesar G M 1998-99 An archaeological survey in the neighbourhood of Thari in the Thar desert (Sindh Pakistan); Ancient Sindh 5 93-118

Datta N P 1962 A rapid colorimetric procedure for the determination of organic carbon in soil; Journal of Indian Society of Soil Science 10 67-74

Day P R 1965 Particle fractionation and particle size analysis. In: Methods of soil analysis Part I (eds) C A Black, D D Evans, J L White, L E Ensminger and F E Clark) (Madison Wisconsin USA: American Society of Agronomy Inc) pp $545-566$

Deodhar L and Kale V S 1999 Downstream adjustments in allochthonous rivers Western Deccan trap region India. In: Varieties of Fluvial Forms (eds) A J Miller and A Gupta pp 295-315 (New York: John Wiley and Sons)

Deotare B C and Kajale M D 1996 Quaternary pollen analysis and palaeoenvironmental studies on the salt basins at Pachpadra and Thob western Rajasthan India preliminary observations; Man and Environment 21(1) 24-31

Deotare B C, Kajale M D, Kshirsagar A A and Rajaguru S N 1998 Geoarchaeological and palaeoenvironmental studies around Bap-Malar playa, District Jodhpur Rajasthan; Current Science 75(3) 316-320

Deotare B C, Kajale M D, Kusumgar S and Rajaguru S N 1999 Late Holocene Environment and Culture at Bari Bavri Western Rajasthan India; Man and Environment 24(1) 27-38

Deotare B C, Kajale M D, Kusumgar S, Gogte V D, Ramesh R, Rajaguru S N, Donahue J D and Jull A J T 2000 Pleistocene - Holocene Climatic changes in Arid Core of the Thar Desert. A case study of Kanod playa District Jaisalmer Rajasthan An extended abstract of the paper presented at the PAGES Workshop on South Asian palaeoenvironments (PW-SAP) February 4-5 2000 at the Institute of Tropical Meteorology, Pune, pp 48-51

Deotare B C and Kajale M D 2002 (Accepted) Lithostratigraphy and Pollen Preservation Potentials of some salt lake deposits in western Rajasthan. In: Landform Processes and Environmental Management (Prof M K Bandopadhyaya Felicitation Volume)

Deshmukh G P and Rai V 1991 Some observations on the origin of saline lakes/ranns of western Rajasthan India; Proceedings of Quaternary Landscapes of Indian Subcontinent pp 41-47 Geology Department, M S University Baroda

Dhir R P, Kar A, Wadhavan S K, Rajaguru S N, Misra V N, Singhvi A K and Sharma S B 1992 Thar Desert in Rajasthan Land Man and Environment Geological Survey of India Bangalore pp 191

Dhir R P, Tondan S K, Rajaguru S N and Ramesh R 1999 Calcretes Their genesis and significance in palaeoclimatic reconstruction in arid Rajasthan India. In: Palaeoecology of Africa and surrounding Islands (ed) K H Heine 25 223-30

Donahue D J, Jull A J T and Zabel T H 1984 Results of radioactivity measurements at the National Science Foundation/University at Arizona tandem mass spectrometry facility; Nucl Instrum and Meth in Phys Res $219162-166$

Enzel Y, Ely L, Mishra S, Ramesh R, Amit R, Lazar B, Rajaguru S N, Baker V R and Sadler A 1999 High Resolution Holocene Environmental Changes in the Thar Desert Northwestern India; Science 284 (2nd April) 125-127

Faegri K and Iversen J 1964 Text book of Pollen Analysis (Oxford: Blackwell Scientific Publications)

Jackson M L 1962 Soil Chemical Analysis (New Delhi: Asia Publishing House)

Juyal N, Kar A, Rajaguru S N and Singhvi A K 2000 Chrono-stratigraphic evidence of episodes of desertifica- tion since last Glacial epoch in the southern margin of the Thar desert India; Paper submitted for the inclusion in the Dubai International Conference on Desertification held between 12-16 February 2000

Kajale M D and Deotare B C 1995 Field Observations and lithostratigraphy of three salt lake deposits in Indian Desert of western Rajasthan; Bulletin of the Deccan College Postgraduate and Research Institute 53 117134

Kajale M D and Deotare B C 1997 Late Quaternary environmental studies on salt lakes in western Rajasthan India a summarised view; Journal of Quaternary Science 12(5) 405-412

Kajale M D, Deotare B C, Kusumgar S, Donahue J D, Jull A J T, Ramesh R, Singhvi A K, Gogte V D and Rajaguru S N 1999 Late Quaternary palaeoenvironmental history of Bap-Malar saline playa in Thar desert of western Rajasthan India-A multidisciplinary approach; An abstract in Quaternary of India (eds) M P Tiwari and D M Mohabey pp 406 Gondawana Geological Magazine No 4 Nagpur

Kajale M D, Rajaguru S N, Deotare B C, Kusumgar S, Singhvi A K, Ramesh R, Gogte V D and Basavaiah N 2000 Late Quaternary climates in Indian Thar desertEvidence from Kanod and Bap-Malar playas; An abstract in Dubai International Conference on Desertification (ed) M A B Fahad held between 12-16 February 2000 pp 198199

Kajale M D, Deotare B C and Rajaguru S N 2002 Paleoenvironmental and paleoclimatic background to the prehistoric cultures of the western and central Thar Desert Rajasthan northwestern India; Proc Second international workshop of Asian Lake Drilling Programme Pune Jan 2001 (in press)

Kale V S, Mishra S and Baker V R 1997 A 2000 years palaeoflood record from Sakargarh on Narmada Central India; Journal of Geological Society of India 50 283-288

Kar A 1995 Geomorphology of Arid western India; Memoir of Geological Society of India 32 168-190

Kar A, Felix C, Rajaguru S N and Singhvi A K 1998 Late Holocene growth and mobility of transverse dune in the Thar desert; Journal of Arid Environments 38 176185

Mehr-Homji V M 1978 Environmental implications of Tertiary plant fossils of India; Indian Journal of Botany 102 $19-27$

Misra V N and Rajaguru S N 1989 Palaeoenvironments and Prehistory of the Thar desert Rajasthan India. In: South Asian Archaeology 1985 (eds) K Frifelt and $\mathrm{R}$ Sorensen, Scandinavian Institute of Asian Studies Occasional papers no 4 Copenhagen

Piper C S 1966 Soil and Plant Analysis (Bombay: Hans Publishers)

Rajagopalan G, Sukumar R, Ramesh R and Pant R K 1997 Late Quaternary vegetational and climatic changes from tropical peat in southern India. An extended record upto 40000 years B P; Current Science 73(1) 60-63

Roy A B 1999 Evolution of Saline Lakes in Rajasthan; Current Science $\mathbf{7 6} 290-295$

Roy P D, Sinha R and Smykatz-Kloss W 2001 Mineralogy and geochemistry of the evaporitic crust from the hyper saline Sambhar lake playa Thar Desert India; Chem Ende 61 241-253

Schick A P 1980 A tentative sediment budget for an extremely arid watershed in the southern Negev In: Geomorphology in Arid Regions (ed) D O Doehring, pp 139164 (London: George Allen and Unwin)

Sharma C and Chauhan M S 1991 Palaeovegetation and palaeoenvironmental inferences from Quaternary 
Palynostratigraphy of the western Indian plains; Man and Environment 15(1) 65-71

Singh G, Joshi R D, Chopra S K and Singh A B 1974 Late Quaternary History of vegetation and climate of the Rajasthan Desert India; Philosophical Transactions of the Royal Society of London 267(889) 467-501

Singh G, Wasson R J and Agrawal D P 1990 Vegetational and seasonal climatic changes since the last full glacial in the Thar Desert northwestern India; Review of Palaeobotany and Palynology 64 351-358

Sinha-Roy S, Malhotra G and Mohanty M 1998 Geology of Rajasthan Geological Society of India Bangalore pp 278

Sinha R and Raymahashay R 2000 Salinity model inferred from two shallow cores at Sambhar salt lake Rajasthan; Journal of Geological Society of India 56 213-217

Slota P J, Jull A J T, Linick T W and Tooling L J 1987 Preparation of small samples for ${ }^{14} \mathrm{C}$ accelerator mass spectrometry targets by catalytic reduction of $\mathrm{CO}_{2}$; Radiocarbon 29(2) 303-306
Traverse A 1988 Palaeopalynology (Boston: Unwin Hyman)

Thomas J V, Kar A, Kailath A J, Juyal N, Rajaguru S N and Singhvi A K 1999 Late Pleistocene-Holocene history of aeolian accumulation in the Thar Desert India; $Z$ Geomorph N F Suppl - Bld 116 181-194

Wadhavan S K and Sharma H S 1997 Quaternary stratigraphy and morphology of desert ranns and evaporite pans in central Rajasthan India; Man and Environment 22(2) $1-10$

Wells S G 1980 Geomorphic control of alluvial fan deposition in the Sonaran desert southwestern Arizona. In: Geomorphology in Arid Regions (ed) D O Doehring pp 27-50 (London: George Allen and Unwin)

Wasson R J, Rajaguru S N, Misra V N, Agrawal D P, Dhir R P, Singhvi A K and Kameshwara Rao K 1983 Geomorphology late Quaternary Stratigraphy and Palaeoclimatology of the Thar dunefield; Z Geomorph $N F$ Suppl Bd 45 117-151 